Supplementary material for the article:

Perendija, J.; Veličković, Z. S.; Cvijetić, I.; Lević, S.; Marinković, A. D.; Milošević, M.; Onjia, A. Bio-Membrane Based on Modified Cellulose, Lignin, and Tannic Acid for Cation and Oxyanion Removal: Experimental and Theoretical Study. Process Safety and Environmental Protection 2021, 147, 609-625. https://doi.org/10.1016/j.psep.2020.12.027. 


\section{Bio-membrane based on Modified Cellulose, Lignin, and Tannic acid for cation and oxyanion removal: experimental and theoretical study}

Jovana Perendija ${ }^{a^{*}}$, Zlate S. Veličkovićb ${ }^{\text {, Ilija Cvijetićc }}$, Steva Levićd, Aleksandar D. Marinkovićf, Milena Miloševića , Antonije Onjia ${ }^{\mathrm{f}}$

${ }^{a}$ University of Belgrade, Institute of Chemistry, Technology and Metallurgy, National Institute of the Republic of Serbia, Njegoševa 12, 11000 Belgrade, Serbia; Tel. +38160 6805 804, email: j.nikolic.ihtm@tesla.rcub.bg.ac.rs (J.Perendija)

milena.milosevic@ihtm.bg.ac.rs (M.Milošević)

${ }^{b}$ Military Academy, University of Defense, Generala Pavla Jurišića Šturma 33, 11000 Belgrade, Serbia; Tel.+381652429 431, email: zlatevel@yahoo.com (Z.S. Veličković)

'Innovation Center, Faculty of Chemistry, University of Belgrade, Studentski trg 12, 11000 Belgrade, Serbia,email: ilija@chem.bg.ac.rs (I. Cvijetić)

${ }^{d}$ University of Belgrade, Faculty of Agriculture, Nemanjina 6, 11080 Belgrade, Serbia; email: slevic@agrif.bg.ac.rs (S. Lević)

${ }^{f}$ University of Belgrade, Faculty of Technology and Metallurgy, Karnegijeva 4, 11060 Belgrade, Serbia; email: marinko@tmf.bg.ac.rs (A.D. Marinković), onjia@tmf.bg.ac.rs (A.Onjia) 


\section{List of symbols}

$\varepsilon \quad$ porosity $(\%)$

$\mathrm{W}_{\mathrm{w}} \quad$ wet sample weight $(\mathrm{g})$

$\mathrm{W}_{\mathrm{d}}$ dry sample weight $(\mathrm{g})$

$\rho_{\mathrm{w}} \quad$ density of pure water $\left(\mathrm{g} \cdot \mathrm{cm}^{-3}\right)$

A area of membrane in the wet state $\left(\mathrm{cm}^{2}\right)$

$\delta \quad$ thickness of membrane in the wet state $(\mathrm{cm})$

$r_{p} \quad$ average pore radius of membrane

$\eta \quad$ water viscosity $\left(8.4 \times 10^{-4} \mathrm{~Pa} \cdot \mathrm{s}\right)$

1 membrane thickness (m)

Q volume of the permeate water per unit time $\left(\mathrm{m}^{3} \cdot \mathrm{s}^{-1}\right)$

A effective area $\left(\mathrm{m}^{2}\right)$

$\varepsilon \quad$ membrane porosity

$\Delta \mathrm{p}$ trans-membrane pressure $(\mathrm{Pa})$

Q equilibrium-swelling ratio

$\mathrm{W}_{\mathrm{h}}$ equilibrium weight of the swollen sample

$\mathrm{W}_{\mathrm{d}}$ weight of the dried sample

$q_{0}$ adsorption capacity of the adsorbent before regeneration $\left(\mathrm{mmol} \cdot \mathrm{g}^{-1}\right)$

$q_{r} \quad$ adsorption capacity of the adsorbent after regeneration $\left(\mathrm{mmol} \cdot \mathrm{g}^{-1}\right)$

$\mathrm{V}$ volume of the permeate $\left(\mathrm{dm}^{3}\right)$

A effective membrane area $\left(\mathrm{m}^{2}\right)$

$\mathrm{T}$ running time (h)

$\mathrm{C}_{\mathrm{p}}$ concentration of permeate

$\mathrm{C}_{\mathrm{f}}$ concentration of feed solution

$C_{e}$ equilibrium adsorbate concentration in the solution $\left(\mathrm{mg} \mathrm{dm}^{-3}\right)$

$q_{e} \quad$ adsorption capacity at equilibrium $\left(\mathrm{mg} \mathrm{g}^{-1}\right)$

$q_{\mathrm{m}} \quad$ maximum adsorption capacity $\left(\mathrm{mg} \mathrm{g}^{-1}\right)$

$K_{L} \quad$ Langmuir isotherm constant

$K_{F} \quad$ Freundlich constant

$n^{-1} \quad$ Freundlich adsorption constant

$R_{L} \quad$ dimensionless equilibrium parameter 
$C_{i} \quad$ initial pollutant concentration $\left(\mathrm{mg} \mathrm{dm}^{-3}\right)$

$B$ Dubinine-Radushkevich (D-R) constant $\left(\mathrm{mol}^{2} \mathrm{~kJ}^{-2}\right)$

$R \quad$ universal gas constant $\left(\mathrm{J} \mathrm{mol}^{-1} \mathrm{~K}^{-1}\right)$

$T$ temperature $(\mathrm{K})$

A Temkin isotherm equilibrium binding constant $\left(\mathrm{dm}^{3} \mathrm{~g}^{-1}\right)$

$b \quad$ Temkin isotherm constant

$\Delta G^{0}$ Gibbs free energy $\left(\mathrm{KJ} \mathrm{mol}^{-1}\right)$

$\Delta H^{0}$ enthalpy change of adsorption $\left(\mathrm{KJ} \mathrm{mol}^{-1}\right)$

$\Delta S^{0}$ entropy change of adsorption $\left(\mathrm{KJ} \mathrm{mol}^{-1}\right)$

$k_{1} \quad$ pseudo-first rate constant $\left(\mathrm{min}^{-1}\right)$

$q_{t} \quad$ adsorption capacity at time $\mathrm{t}\left(\mathrm{mg} \mathrm{g}^{-1}\right)$

$t$ time (min)

$k_{2}$ the second-order rate constant $\left(\mathrm{g} \mathrm{mg}^{-1} \mathrm{~min}^{-1}\right)$

$h_{2} \quad$ initial sorption rate at $\mathrm{t} \rightarrow 0\left(\mathrm{mg} \mathrm{g}^{-1} \mathrm{~min}^{-1}\right)$

$k_{i} \quad$ intraparticle diffusion rate constant $\left(\mathrm{mg} \mathrm{g}^{-1} \min ^{1 / 2}\right)$

$C_{B L} \quad$ constant related to the thickness of the boundary layer

$K$ rate constant of adsorption $\left(\mathrm{min}^{-1}\right)$

$R \quad$ initial radius of the reacting particle

$\alpha$ fractional completion of reactions at time $t$

$D$ diffusion coefficient of the migrating species

$k_{\text {DW }}$ Dunwald-Wagner isothermal reaction constant

$D$ s intraparticle diffusion coefficient

$R \quad$ radial position

$R$ distance from the center of adsorbent particle during adsorption

$C_{0} \quad$ initial concentration of heavy metal $\left(\mathrm{mol} \mathrm{dm}^{-3}\right)$

$\mathrm{C}_{\mathrm{t}}$ concentration of heavy metal at time $t\left(\mathrm{~mol} \mathrm{dm}{ }^{-3}\right)$

$T \quad$ flow time (min)

$\Theta \quad$ time required for $50 \%$ breakthrough (min)

$K_{\text {YN }}$ the Yoon-Nelson rate constant $\left(\mathrm{min}^{-1}\right)$

$\mathrm{Z}$ bed depth of column $(\mathrm{cm})$

$\mathrm{N}_{0}$ maximum uptake capacity per unit volume of adsorbent column $\left(\mathrm{mg} \mathrm{dm}^{-3}\right)$

$\mathrm{U}_{0} \quad$ linear velocity of influent solution $\left(\mathrm{cm} \mathrm{min}^{-1}\right)$

$\mathrm{K}_{\mathrm{AB}}$ the kinetic constant $\left(\mathrm{dm}^{3} \mathrm{mg}^{-1} \mathrm{~min}^{-1}\right)$

$C \quad$ sorbate concentration in the effluent $\left(\mathrm{mmol} \cdot \mathrm{dm}^{-3}\right)$ 
$C_{0} \quad$ sorbate concentration in the feed solutions $\left(\mathrm{mmol} \cdot \mathrm{dm}^{-3}\right)$

$U_{0} \quad$ linear flow rate $\left(\mathrm{cm} \cdot \mathrm{min}^{-1}\right)$

$Z \quad$ the bed column depth $(\mathrm{cm})$

$t \quad$ adsorption time ( $\min )$

$\beta \quad$ kinetic coefficient of the external mass transfer $\left(\min ^{-1}\right)$

$N_{0} \quad$ volumetric saturation capacity of the adsorbent $\left(\mathrm{mmol} \cdot \mathrm{dm}^{-3}\right)$

$n \quad$ Freundlich constant

$C_{\mathrm{b}} \quad$ concentration at breakthrough $\left(\mathrm{mmol} \cdot \mathrm{dm}^{-3}\right)$

$k_{\mathrm{T}} \quad$ mass-transfer rate coefficient $\left(\mathrm{min}^{-1}\right)$

$v \quad$ migration velocity of the concentration fronts in the bed $\left(\mathrm{cm} \cdot \mathrm{min}^{-1}\right)$

$\mathrm{V} \quad$ volume of the permeate $\left(\mathrm{dm}^{3}\right)$

\section{Experimental part}

\subsection{Chemicals and materials}

All the chemicals used in this study were of analytical grade and used as received. The following chemicals were supplied from Sigma Aldrich, Germany: sulfuric acid, hydrogen peroxide, ethanol 96\%, dimethyl sulfoxide (DMSO), lithium chloride (LiCl), dimethylformamide (DMF), epichlorohydrin (ECH), tetrabutylammonium chloride (TBAC), sodium hydroxide $(\mathrm{NaOH})$, Tetrahydrofuran (THF), pyridine, 3-(carbomethoxy) propionyl chloride (CPC), diethylenetriamine (DETA), methanol. 3-glycidoxypropyltrimethoxy-silane (GLYMO) was supplied from Evonik Resource Efficiency GmbH , Germany. Waste cellulose paper was supplied by “Just paper doo", Barič, Serbia (material was collected after obtaining official permission). Commercial lignin, kraft was supplied by Sigma Aldrich (Merck). The $\mathrm{Ni}^{2+}, \mathrm{Pb}^{2+}$ and $\mathrm{Cr}(\mathrm{VI})$, stock solutions were prepared with deionized water (DW), resistivity $18 \mathrm{M} \Omega \mathrm{cm}$, using standards of Nickel AA and Lead AA, $1000 \mu \mathrm{g} / \mathrm{ml}$ (Accustandard)), respectively, and Chromium AA, $1000 \mu \mathrm{g} / \mathrm{ml}$ (Merck, Germany). Adjustment of $\mathrm{pH}$ was accomplished with $0.1 \mathrm{M} \mathrm{NaOH}$ and $0.1 \mathrm{M} \mathrm{HNO}_{3}$ (Sigma Aldrich). 


\subsection{Characterization of adsorbents}

\subsubsection{Uniaxial Mechanical testing}

The tensile tests of the Cell, Cell-TA, Cell-EL and Cell-EL-TA in dry condition were performed, using a Universal Testing Machine, Shimadzu Autograph AGS-X plus (Japan), equipped with a $1 \mathrm{kN}$ load cell. The gauge length was $30 \mathrm{~mm}$, thickness was $3 \mathrm{~mm}$ and width on $4.5 \mathrm{~mm}$. Tensile strength tests were conducted with a constant cross head speed of 2 $\mathrm{mm} / \mathrm{min}$.

\subsubsection{FTIR spectroscopy}

Fourier-Transfer Infrared Spectroscopy analysis (FTIR) of samples was performed using Thermo Scientific Nicolet 6700 spectrometer in the attenuated total reflectance (ATR) mode, United States of America. The range of wavenumber was $3500-500 \mathrm{~cm}^{-1}$.

\subsubsection{Raman spectroscopy}

Raman spectra were collected with a XploRA Raman spectrometer from Horiba Jobin Yvon, France. The system employed laser at $785 \mathrm{~nm}$ and all measurements were realized using the spectrometer equipped with a $1200 \mathrm{gr} / \mathrm{mm}$ grating, while acquisition time was $30 \mathrm{~s}$. The Raman spectrometer was connected with an optical microscope equipped with a motorized stage and 50x long working distance objective was used for sample investigation and laser focusing.

\subsubsection{Surface Morphology analysis}

The surface morphology of the samples were examined using a Tescan Mira3 XMU field emission scanning electron microscope (FE-SEM), operated at $20 \mathrm{kV}$, Czech Republic.

\subsubsection{Image analysis, Membrane porosity and Pore size of the membrane}

Software Image-Pro Plus 6.0 was used to obtain the statistical data of the pore size diameters and overall surface porosity of the Cell-EL and Cell-EL-TA membranes.

Membrane porosity also was determined according to the dry-wet weight method. The porosity (\%) was calculated as a function of the membrane weight, Eq. S1 (Koromilas et al., 2019):

$\operatorname{Porosity}(\%)=\frac{W_{w}-W_{d}}{\rho_{w} \cdot A \cdot \delta} \times 100$

Where, $W_{w}$ is the wet sample weight $(\mathrm{g}), \mathrm{W}_{\mathrm{d}}$ is the dry sample weight $(\mathrm{g}), \rho_{\mathrm{w}}$ is the density of pure water $\left(\mathrm{g} / \mathrm{cm}^{3}\right), A$ is the area of membrane in the wet state $\left(\mathrm{cm}^{2}\right)$, and $\delta$ is the thickness of membrane in the wet state $(\mathrm{cm})$. 
The average pore radius of membranes is calculated by the following Guerout-Ferry equation Eq. S2 (Yuan et al., 2013):

$r_{p}=\sqrt{\frac{(2.9-1.75 \cdot \varepsilon) \cdot 8 \eta \cdot l \cdot Q}{\varepsilon \cdot A \cdot \Delta p}}$

Where, $\eta$ is the water viscosity $\left(8.4 \times 10^{-4} \mathrm{~Pa} \cdot \mathrm{s}\right), 1$ is the membrane thickness $(\mathrm{m}), Q$ is the volume of the permeate water per unit time $\left(\mathrm{m}^{3} \cdot \mathrm{s}^{-1}\right)$, A is the effective area $\left(\mathrm{m}^{2}\right), \varepsilon$ is the membrane porosity and $\Delta \mathrm{p}$ is the trans-membrane pressure $(\mathrm{Pa})$.

The equilibrium-swelling ratio

Experiment was performed as follows: a piece of the membrane was immersed in distilled water for 5 days until it reached the swelling-equilibrium state, and then removed from the solution. Excess water from the surface is wiped off, and the wet membrane was weighed, then the membrane was dried in a vacuum oven at $70{ }^{\circ} \mathrm{C}$ for about $48 \mathrm{~h}$ and reweighed. The equilibrium-swelling ratio (Q) was calculated from the Eq. S3 (Liu et al., 2010):

$Q=\frac{W_{h}-W_{d}}{W_{d}}$

where $W_{\mathrm{h}}$ is the equilibrium weight of the swollen sample and $\mathrm{W}_{\mathrm{d}}$ is the weight of the dried sample.

\subsubsection{Determination of hydroxyl and carboxylic groups in kraft lignin}

The content of total $\mathrm{OH}$ groups in lignin was determined by the method of acetylation of samples with acetic anhydride followed by potentiometric titration of free acetic acid in excess with $0.1 \mathrm{~N} \mathrm{NaOH}$ in water (Jablonskis et al., 2018)

Determination of the phenolic hydroxyl and carboxylic groups was performed by a nonaqueous potentiometric titration with tetra-n-butylammonium hydroxide (TnBAH). A $0.15 \mathrm{~g}$ of air-dried lignin and $0.02 \mathrm{~g}$ p-hydroxybenzoic acid as internal standard were used. The dissolving time of the lignin in DMF was prolonged to 15 min (Gosselink et al., 2004; Serrano et al., 2018). Aliphatic hydroxyl content of lignin was calculated from the difference of determined phenolic and total hydroxyl groups.

The results of hydroxyl and carboxyl groups determination is given in Table S4.

\subsubsection{Amino group and epoxy equivalent weight (EEW) determination}

Quantification of the available amino group was determined via "back" (indirect)

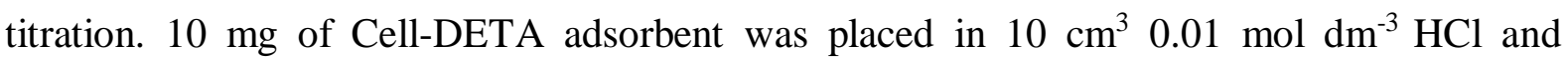


ultrasonicated for $15 \mathrm{~min}$. Materials were filtered, and $10 \mathrm{~cm}^{3}$ of supernatant was titrated with a standard solution of $0.01 \mathrm{~mol} \mathrm{dm}{ }^{-3} \mathrm{KOH}$ in the presence of methyl orange indicator. Epoxy equivalent weight (EEW) was determined as follows: $100 \mathrm{mg}$ of sample were placed in $10 \mathrm{~cm}^{3}$ of methylene chloride and $10 \mathrm{~cm}^{3}$ of tetraethylammonium bromide indicator solution. Then, the mixture was titrated with a $0.1 \mathrm{~N}$ standard solution of perchloric acid in the presence of crystal violet indicator until the color changed from crystal violet to green. (ASTM D1652).

\subsection{Batch adsorption experiments}

The concentrations of metal ions $\left(\mathrm{Pb}^{2+}, \mathrm{Ni}^{2+}\right.$ and $\left.\mathrm{Cr}(\mathrm{VI})\right)$ were measured by atomic absorption spectrometry (AAS) using a Perkin Elmer PinAAcle 900T, USA. In order to evaluate the performance of the Cell-EL and Cell-EL-TA, batch adsorption experiments were conducted by equilibration of $\mathrm{Pb}^{2+}, \mathrm{Ni}^{2+}$ and $\mathrm{Cr}(\mathrm{VI})$ adsorbate solution under magnetic stirring. Adsorption experiments were performed by addition of 1, 2, 3, 4, 5, 7.5 and $10 \mathrm{mg}$ of adsorbent in a vials of $8 \mathrm{~mL}$ containing $11.0,10.5$ and $12.0 \mathrm{mg} \mathrm{dm}{ }^{-3}$ of standard solutions of $\mathrm{Pb}^{2+}, \mathrm{Ni}^{2+}$ and $\mathrm{Cr}(\mathrm{VI})$, respectively. Optimal $\mathrm{pH}$ was defined at 7 for $\mathrm{Pb}^{2+}, \mathrm{Ni}^{2+}$ and $\mathrm{Cr}(\mathrm{VI})$ using CellEL-TA, while pH 6 for Cell-EL. Adsorption equilibrium and thermodynamic parameters were evaluated at three temperatures $\left(25,35\right.$ and $\left.45{ }^{\circ} \mathrm{C}\right)$. The adsorption kinetic was studied by varying the contact time: $1,5,15,30,45,60,75,90$ minutes and $24 \mathrm{~h}$ at $C_{\mathrm{i}}=11.0,10.5$ and $12.0 \mathrm{mg} \mathrm{dm}^{-3}$ for $\mathrm{Pb}^{2+}, \mathrm{Ni}^{2+}$ and $\mathrm{Cr}(\mathrm{VI})$, respectively, $\mathrm{pH}_{\mathrm{i}} 7$ for Cell-EL-TA and 6 for Cell-EL, at 25,35 and $45{ }^{\circ} \mathrm{C}$. After adsorption the sample solutions were filtered through a nylon membrane syringe filter (pore size $0.22 \mu \mathrm{m}$ ). The $\mathrm{Pb}^{2+}, \mathrm{Ni}^{2+}$ and $\mathrm{Cr}(\mathrm{VI})$ uptake of adsorbent adsorbed per mass unit of the adsorbent were calculated from the Eq. S4 (Ren et al., 2017):

$$
q=\frac{\left(C_{i}-C_{f}\right)}{m} V
$$

where $q$ is the adsorption capacity in $\mathrm{mg} \mathrm{g}^{-1}, C_{i}$ and $C_{f}$ are the initial and final concentrations of ions in the solution in $\mathrm{mg} \mathrm{dm}^{-3}, V$ is the volume of solution in $\mathrm{dm}^{-3}$, and $m$ is the mass of the adsorbent in $\mathrm{g}$. Adsorption isotherms are determined as the dependence of $\mathrm{q}, \mathrm{mg} \mathrm{g}^{-1}$ from equilibrium concentration $\mathrm{Ce}, \mathrm{mg} \mathrm{dm}^{-3}$ based on the calculated values of $q$. Calculated values were fitted to four models of adsorption isotherms (Langmuir, Freundlich, Temkin and Dubinin-Radushkevich (D-R) models).

The removal efficiency ( $\mathrm{R} \%$ ) of the adsorbent was calculated with the following formula:

$\mathrm{R}(\%)=\left[\frac{C_{i}-C_{e}}{C_{i}}\right] \times 100$ 


\section{Desorption study}

The success/approval for an application of new adsorption technologies, used in the processes of water purification, strongly depends on established sustainable development indices as criteria for process validation and potential application. Thus in order to fulfill such requirement the adsorbent with the lowest degree of deterioration after desorption and solving of proper effluent solution treatment with proper disposal.

Alkaline and acidic regenerators are usually used in the process of $\mathrm{Cr}(\mathrm{VI})$ and cations desorption. Their efficiencies strongly depend on the adsorbate/surface functionalities bonding types. Higher acidity/basicity and increased concentration of regenerator could more effectively compete with the bonded ion, and thus the efficient desorption would be expected. In the other hand two undesirable effects: due to nucleophilicity of hydroxide ion hydrolysis of ester bond take place as well as de-protonation of acidic sites at adsorbent surface.

The regeneration of the Cell-EL and Cell-EL-TA were studied using different desorption agents such as $\mathrm{NaOH}, \mathrm{Na}_{2} \mathrm{CO}_{3}, \mathrm{KOH}$, conc. $\mathrm{HCl}$ and sulfuric acid, oxalic acid, citric acid were used. Desorption methodology was analogously applied as in recent published paper (Perendija et.al., 2020), and the most efficient processes were obtained using $0.5 \mathrm{~mol} \mathrm{dm}^{-3} \mathrm{HCl}$ and $0.5 \mathrm{~mol} \mathrm{dm}^{-3} \mathrm{NaOH}$.

The regeneration efficiency (\%RE) of the adsorbent was calculated as follows:

$(\% R E)=\frac{q_{r}}{q_{0}} \times 100$

Where $q_{0}$ and $q_{\mathrm{r}}$ are the adsorption capacities of the adsorbents $(\mathrm{mmol} / \mathrm{g})$ before and after desorption step, respectively. Desorption efficiency represent percent of the amount of pollutant $\left(\mathrm{Ni}^{2+}, \mathrm{Pb}^{2+}\right.$ and $\left.\mathrm{Cr}(\mathrm{VI})\right)$ desorbed to the amount of pollutant adsorbed per mass unit of adsorbent. The obtained results are given in Table 8 .

Three consecutive adsorption/desorption cycles were performed in triplicate. All collected effluent water was analyzed using atomic absorption spectrometry (AAS) using a Perkin Elmer PinAAcle 900T. The eluent was separated from the adsorbent by filtration in a vacuum through a PTFE filter with a $0.22 \mu \mathrm{m}$ pore diameter.

\section{Precipitation of $\mathrm{Ni}^{2+}, \mathrm{Pb}^{2+}$ and $\mathrm{Cr}(\mathrm{VI})$ ) from desorption solution}

Nowadays, the treatment of processed effluents is the most serious environmental issue, due to toxic metals present at high concentrations which possess hazardous characteristics. Selection of the most efficient technology for the effluent water processing, e.g. precipitation, ion exchange, filtration etc., was a first step following by optimization procedure. Precipitation 
is simple and cost-effective method, and thus different precipitating ahent was used in this study.

The precipitation of lead and nickel in a batch system $(100 \mathrm{~mL})$ at $25 \pm 1^{\circ} \mathrm{C}$ by addition of either $\mathrm{Ca}(\mathrm{OH})_{2}, \mathrm{CaO}$ or $\mathrm{MgO}$ to the heavy metal solutions. After agitation at $250 \mathrm{rpm}$ for 30 min using a magnetic stirrer, the solution was subjected to gentle stirring at jar test (150 rpm) for 90 min to attain completion of precipitation. The suspensions were left to settle for 60 - 90 min depending on precipitant, and the supernatant from each experiment was collected and acidified to $\mathrm{pH}<2$, filtered and analyzed.

In order to investigate the feasibility of lead removal, the industrial effluent containing lead $(10 \mathrm{mg} / \mathrm{L})$ from electroplating was treated. The precipitation experiment, performed by (Kavak, 2013), was carried out at optimum conditions $\mathrm{pH}=12$; mass of precipitating agent $=$ $0.75 \mathrm{~g} / \mathrm{L}$ and precipitation time $=30 \mathrm{~min}$. A very high lead removal efficiency of $99.5 \%$ was reached.

Precipitation of $\mathrm{Cr}$ (III) was carried out by adding the weighed precipitate agent into the sample and then mixing for $5 \mathrm{~min}$ with a mechanical agitator so that the alkali dissolved completely. The solution $\mathrm{pH}$ was measured after the alkali dissolved ( $\mathrm{pH} 8.13)$, and after the reaction was complete $(\mathrm{pH} 8.0)$. The precipitate sedimentation was finished in a $3 \mathrm{~h}$ period (Guo et al., 2006).

The solubility of the metal sulfide precipitates is considerably lower than hydroxide precipitates and sulphide precipitates are not amphoteric. Consequently, the sulfide precipitation process can achieve a high degree of metal removal over a broad $\mathrm{pH}$ range compared with hydroxide precipitation. Also, sulphide precipitation reaction rate is faster than hydroxide precipitation due to the high reactivity between sulphide and heavy metal ions (Ain Zainuddin et al., 2019). One more advantage is that metal sulfide sludge also shows better thickening and dewatering characteristics than the analogous metal hydroxide sludge and metals can be easily extracted and reprocessed (Fu and Wang, 2011). In this study, the $\mathrm{Pb}^{2+}$ precipitates as its sulphide using iron sulphide. The maximum precipitation of $\mathrm{Pb}^{2+}(360-520$ $\mathrm{mg} / \mathrm{L})$ was determined to be $99.8 \%$ at the following conditions: adsorbent dosage (12 $\mathrm{g} / \mathrm{L})$, time: 45 minutes and pH value 5 (Özverdi and Erdem, 2006). For the removal of $\mathrm{Ni}^{2+}$, sodium sulphide $\left(\mathrm{Na}_{2} \mathrm{~S}\right)$ was used as the precipitant, and $\mathrm{NaOH}$ to prevent the producing harmful hydrogen sulphide. The high removal efficiency of nickel was achieved by sulphide precipitation $(96.10 \%)$. It was concluded that $\mathrm{pH} 10-10.5$ is the optimum $\mathrm{pH}$ for nickel removal, as similarly recently published (Ain Zainuddin et al., 2019). 


\subsubsection{Leaching experiment - Toxicity Characteristic Leaching Procedure (TCLP)}

In order to examine the ecotoxicity of the remaining filter cake after filtration of the precipitated heavily soluble salts, i.e. hydroxide, chromate, phosphate and sulfide. TCLP test was performed. The obtained results provide the capabilities of the stabilized materials for the potential release of the metal ions into environment, and provided proof of eco-safety, The experimental procedure was conducted according to the Toxicity Characteristic Leaching Procedure (TCLP) and U.S. EPA method 1311 (Bestgen et al., 2016; Mahedi et al., 2019). According to TCLP requirements, the following choice of extraction medium is proposed: Fluid $-5.7 \mathrm{~mL}$ of glacial acetic acid, $\mathrm{HOAc}$ and $64 \mathrm{~mL}$ of $1 \mathrm{M}$ sodium hydroxide, $\mathrm{NaOH}$ (the $\mathrm{pH}$ value of $\mathrm{NaOAc}$ solution was 4.93 \pm 0.05 ) (Mahedi et al., 2019).

The concentration of heavy metals (chromium, cadmium, lead, zinc, copper and nickel) in membrane wastes was determined according to the following procedure: $1 \mathrm{~g}$ of the sample, previously chopped in a crucible, was burn on a flame and buried at $450^{\circ} \mathrm{C}$ to constant mass. Then was added 1-2 ml of deionized water, evaporated to dryness, added 1-2 ml of concentrated $\mathrm{HCl}$, filtered into a normal $10 \mathrm{ml}$ vessel and maked up to volume with deionized water. The metal concentration was further determined using AAS technique. The metal content was calculated using the following equation Eq. S7:

$\frac{c \times V}{m}=m g / k g$

where, $\mathrm{c}$ is measured metal concentration in $\mathrm{mg} \mathrm{dm}^{-3}$, volume of solution in $\mathrm{dm}^{3}$, and $\mathrm{m}$ is measured mass of sample in $\mathrm{kg}$.

The leaching test also was performed for the potential release of the metals from CellEL and Cell-EL-TA after regeneration (Table S12, S13) in order to prove eco-safety of the treated materials (U.S. EPA method 1311). Thus, membrane after forth cycle was subjected to a process of incineration at around $700{ }^{\circ} \mathrm{C}$ for $1 \mathrm{~h}$ to ash. Ash samples $(5 \mathrm{mg})$ were mixed with $25 \mathrm{ml}$ of deionized water, stirring for $24 \mathrm{~h}$ (Banerjee et al., 2018) and the filtrate was analysed for $\mathrm{Pb}^{2+}, \mathrm{Ni}^{2+}$ and $\mathrm{Cr}(\mathrm{VI})$ where it was proven that heavy metal concentrations were below the prescribed limit values.

\subsubsection{Membrane performance}

The $\mathrm{pH}$ of the point of zero charge, $\mathrm{pH}_{\mathrm{PZC}}$, is the $\mathrm{pH}$ above which the total surface of the Cell-EL and Cell-EL-TA is negatively charged, and it was measured by the so-called pH drift method. Regarding the pHPzC of Cell-EL and Cell-EL-TA, in solution having $\mathrm{pH}$ value lower than $\mathrm{pH}$ PZC of Cell-EL and Cell-EL-TA, the surface sites could be protonated and 
positively charged. On the other hand, the active sites are deprotonated when the solution $\mathrm{pH}$ is higher than $\mathrm{pH}$ PZC, resulting in negatively charged sites and the adsorption of metal cations on Cell-EL and Cell-EL-TA could possibly take place via electrostatic interaction with the negatively charged sites on Cell-EL and Cell-EL-TA. Point of zero charge ( $\mathrm{pH}_{\mathrm{PZC}}$ ) was also determined using method described by Milonjić et al (Milonjić et al., 1975).

For the $\mathrm{pH}$ measurements a laboratory $\mathrm{pH}$ meter, InoLab Cond 730 precision conductivity meter (WTW GmbH), with an accuracy of $\pm 0.01 \mathrm{pH}$ units, was used.

\subsubsection{Permeation properties}

The membrane permeation flux is defined as the volume flowing through the membrane per unit area per unit time and can be expressed by the following equation:

$\mathrm{J}=\frac{\mathrm{V}}{\mathrm{At}}$

where $V$ is the volume of the permeate $\left(\mathrm{dm}^{3}\right), \mathrm{A}$ is the effective membrane area $\left(\mathrm{m}^{2}\right)$ and $t$ is the running time (h). The water treatment performance test was carried on the obtained membranes. The rejection was calculated by the following equation:

Rejection $(\%)=\left(1-\frac{C p}{C f}\right) \times 100 \%$

The dye permeate flux, Eq. (S8), was determined in order to study the permeation properties of Cell-EL and Cell-EL-TA, while the rejection ratio $(R)$, calculated by using Eq. (S9), define rejection capability of produced membranes. As in our recently published paper, using designed set-up for a cross-flow filtration (Perendija et. al. 2020), aqueous DR80 and three range of the molecular weight of sodium alginate (200 ppm) was used in permeation experiments. The micro range of average pore size of both membranes indicates potential filterability of Cell-EL and Cell-EL-TA to hold out high water flux. The porosity determination gave 54\% for Cell-EL, and 48 for Cell-EL-TA (Table 1). Moderate membrane porosity provide a condition for appreciable loading flux using Cell-EL and Cell-EL-TA with similar surface properties and different porous network (textural properteis0) which provide remarkable transportability across to porous network. The water permeability, i.e. water flux, of the CellEL and Cell- membranes was evaluated in cross-flow system at the variable rate condition (Perendija et. al. 2020). The obtained results are given in Fig. S1. 


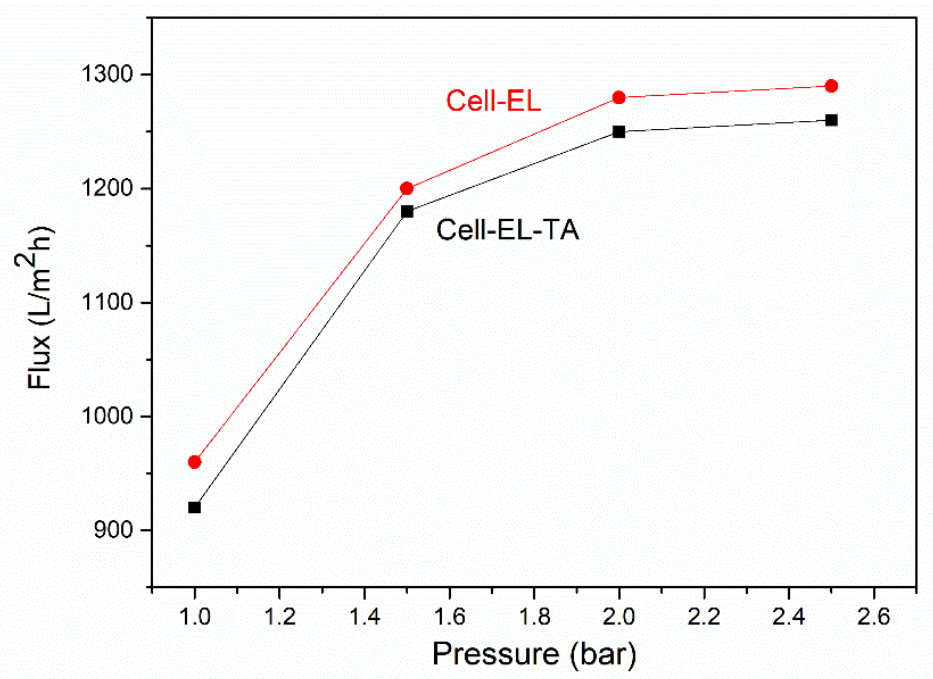

Fig. S1. Water flux versus pressure for Cell-EL and Cell-EL-TA

From the Fig. S1 it can be seen that flux was significant at pressure until 2.5 bar, and after it increase steadily until membrane rupture. The water permeability was $920 \mathrm{~L} \mathrm{~m}^{-2} \mathrm{~h}^{-1}$ bar $^{-}$ ${ }^{1}$ for the Cell-EL-TA, while somewhat higher value was obtained for Cell-EL $\left(960 \mathrm{~L} \mathrm{~m}^{-2} \mathrm{~h}^{-1}\right.$ bar $^{-1}$. Produced membranes have comparative higher or similar flux in comparison to published results, which depend on pores diameter/structure and present functionalities. In general, it means that similar material properties, porosity and surface chemistry provide condition for similar hydrodynamic behavior of both adsorbents.

\subsection{Bed column experiments}

Cell-EL and Cell-EL-TA adsorbents were carefully cut and packed into a glass column to achieve optimal system packing. A glass tubes of $1.5 \times 6 \mathrm{~cm}(\mathrm{~d} \times \mathrm{H})$ with a sintered filter and PTFE valve packed with Cell-EL and Cell-EL-TA were used to conduct the flow-through column experiment with a down-flow design. Sand was added to the top of the column bed after pre-treatment to prevent an even flow distribution. A column adapter was attached to the top of the column to allow PTFE tubing to be fitted into the column. Prior to the column being attached, the feeding solution (DW) was pumped through the tubing to remove any impurities from the rig. After the addition of DW, a vacuum was applied to remove air bubbles trapped during inflow of feeding solution. The effluent samples were collected at a predetermined period of time and the concentration of $\mathrm{Pb}^{2+}, \mathrm{Ni}^{2+}$ and $\mathrm{Cr}(\mathrm{VI})$ in the effluent was determined using AAS technique. The mass of adsorbents in the columns were: $m_{\mathrm{ads}}($ Cell-EL $)=487.5 \mathrm{mg}$ and $m_{\text {ads }}($ Cell-EL-TA $)=502.5 \mathrm{mg}$. The solutions of pollutants $\left(C_{\mathrm{i}}=11.0,10.5\right.$ and $12.0 \mathrm{mg}$ $\mathrm{dm}^{-3}$ for $\mathrm{Pb}^{2+}, \mathrm{Ni}^{2+}$ and $\mathrm{Cr}(\mathrm{VI})$, respectively, of known concentration was adjusted to $\mathrm{pH} 6$ and 7 for Cell-EL and Cell-EL-TA, respectively, passed through the column at $0.5,1.0$ and $1.5 \mathrm{~cm}^{3}$ 
$\min ^{-1}$ flow rate, respectively. Samples were collected at regular intervals and the concentrations of heavy metals in the effluent were analysed using a AAS spectrophotometer (Perkin Elmer PinAAcle 900T).

The flow rate $Q$, empty bed volume $(E B V)$, and $\mathrm{pH}$-value were adjusted to obtain optimal empty bed contact time (EBCT). The flow rate of feed solution was varied at $Q=0.5$, 1.0 and $1.5 \mathrm{~cm}^{3} \mathrm{~min}^{-1}$. All experiments were performed at $25^{\circ} \mathrm{C}$. The feed water was allowed to pass through the hybrid adsorbent bed using peristaltic pump Ismatec. Residence time $E B C T$ was calculated according to: $E B C T=\mathrm{H} / \gamma$, where $\mathrm{H}$ is bed depth $(1.92 \mathrm{~cm}$ for Cell-EL and 1.76 $\mathrm{cm}$ for Cell-EL-TA) and $\gamma$ is thelinear flow rate $\left(\mathrm{cm}^{3} \mathrm{~cm}^{-2} \mathrm{~s}^{-1}\right)$.

\subsection{Response surface methodology (RSM): experimental design of adsorbent preparation}

RSM is a powerful statistical tool for design and analysis of experiments aimed at the optimization of complex chemical and physical processes (Aniceto et al., 2016).

The influence of membrane synthesis parameters (Table S1) and adsorption parameters (Table S2) was performed using response surface methodology (RSM). D-optimum design, with 3 Numerical Factors that minimizes variances associated with the estimates of coefficients for the model, is used. The coded and operational values of the selected variables are shown in Table S1 and S2, together with the experimental plan, which included 23 experimental cycles with five repetitions. Each experiment (except the center point) is performed in duplicate. The output variable was the breakthrough time. Experimental data were fitted with a second-order polynomial equation and the coefficients of the response function and their statistical significance were evaluated by the least-squares method using commercial software DesignExpert, Software Version 9 (Stat-Ease, Inc. 2021 E. Hennepin Ave. Suite 480 Minneapolis, USA). The ANOVA test was used to determine the adequacy of the model used.

More precise optimization conditions are obtained by point prediction through the software based on the factors or components included in the model. The operational values of the selected variables are shown in Tables $\mathrm{S} 1$ and $\mathrm{S} 2$, together with the experimental design, which included 23 experimental runs with five repetitions. 
Table S1. Design matrix and the results of the five-level and three-factor D-optimal design

\begin{tabular}{cccccc}
\hline \multirow{2}{*}{$\begin{array}{c}\text { Run } \\
\text { number }\end{array}$} & $\begin{array}{c}X_{1} \text { : Cell-Glymo/EL, } \\
(\text { wt. \%) }\end{array}$ & $\begin{array}{c}\mathrm{X}_{2} \text { : Cell- } \\
\text { DETA, } \\
(\text { wt. } \%)\end{array}$ & $\begin{array}{c}\mathrm{X}_{3}: \\
\text { Temperature, } \\
\left({ }^{\circ} \mathrm{C}\right)\end{array}$ & $\begin{array}{c}\text { Actual } q_{\text {max }} \text { for } \\
\mathrm{Ni}^{2+}\left(\mathrm{mg} \mathrm{g}^{-1}\right)\end{array}$ & Predicted \\
\hline 1. & 1.5 & 20 & 70 & 22.59 & 22.58 \\
2. & 2.5 & 20 & 70 & 22.28 & 22.14 \\
3. & 1.5 & 30 & 70 & 21.49 & 21.72 \\
4. & 2.5 & 30 & 70 & 24.45 & 24.02 \\
5. & 1.5 & 20 & 90 & 24.45 & 24.35 \\
6. & 2.5 & 20 & 90 & 25.63 & 24.85 \\
7. & 1.5 & 30 & 90 & 23.66 & 23.24 \\
8. & 2.5 & 30 & 90 & 27.02 & 26.49 \\
9. & 1.5 & 20 & 70 & 22.59 & 22.58 \\
10. & 2.5 & 20 & 70 & 22.28 & 22.14 \\
11. & 1.5 & 30 & 70 & 21.49 & 21.72 \\
12. & 2.5 & 30 & 70 & 24.45 & 24.02 \\
13. & 1.5 & 20 & 90 & 24.45 & 24.35 \\
14. & 2.5 & 20 & 90 & 25.63 & 24.87 \\
15. & 1.5 & 30 & 90 & 23.66 & 23.24 \\
16. & 2.5 & 30 & 90 & 27.02 & 26.49 \\
17. & 1 & 25 & 80 & 19.52 & 19.59 \\
18. & 3 & 25 & 80 & 20.70 & 22.39 \\
19. & 2 & 15 & 80 & 20.05 & 20.86 \\
20. & 2 & 35 & 80 & 20.70 & 21.65 \\
21. & 2 & 25 & 60 & 23.66 & 23.79 \\
22. & 2 & 25 & 100 & 26.36 & 27.97 \\
23. & 2 & 25 & 80 & 24.85 & 26.49 \\
\hline
\end{tabular}


Table S2. Design matrix and the results of the five-level and three-factor D-optimal design

\begin{tabular}{|c|c|c|c|c|c|}
\hline \multirow[b]{2}{*}{$\begin{array}{l}\text { Run } \\
\text { number }\end{array}$} & \multicolumn{3}{|c|}{ Conditions } & \multicolumn{2}{|c|}{ Respons } \\
\hline & $\begin{array}{c}X_{1} \text { : Cell-Glymo/EL, } \\
\text { (wt. \%) }\end{array}$ & $\begin{array}{c}\mathrm{X}_{2}: \\
\text { TA/Cell- } \\
\text { DETA, } \\
\text { (wt.\%) }\end{array}$ & $\begin{array}{c}\mathrm{X}_{3}: \\
\text { Temperature, } \\
\left({ }^{\circ} \mathrm{C}\right)\end{array}$ & $\begin{array}{l}\text { Actual } q_{\max } \text { for } \\
\mathrm{Cr}(\mathrm{VI})\left(\mathrm{mg} \mathrm{g}^{-1}\right)\end{array}$ & Predicted \\
\hline 1. & 1.5 & 0.75 & 50 & 48.84 & 49.04 \\
\hline 2. & 2.5 & 0.75 & 50 & 54.08 & 57.51 \\
\hline 3. & 1.5 & 1.25 & 50 & 67.70 & 66.35 \\
\hline 4. & 2.5 & 1.25 & 50 & 63.81 & 68.51 \\
\hline 5. & 1.5 & 0.75 & 70 & 72.86 & 72.80 \\
\hline 6. & 2.5 & 0.75 & 70 & 60.18 & 62.06 \\
\hline 7. & 1.5 & 1.25 & 70 & 71.29 & 70.91 \\
\hline 8. & 2.5 & 1.25 & 70 & 71.29 & 73.66 \\
\hline 9. & 1.5 & 0.75 & 50 & 65.38 & 66.35 \\
\hline 10. & 2.5 & 0.75 & 50 & 56.32 & 57.51 \\
\hline 11. & 1.5 & 1.25 & 50 & 67.70 & 66.35 \\
\hline 12. & 2.5 & 1.25 & 50 & 71.29 & 68.51 \\
\hline 13. & 1.5 & 0.75 & 70 & 72.86 & 72.80 \\
\hline 14. & 2.5 & 0.75 & 70 & 60.18 & 62.06 \\
\hline 15. & 1.5 & 1.25 & 70 & 71.29 & 70.90 \\
\hline 16. & 2.5 & 1.25 & 70 & 71.29 & 71.16 \\
\hline 17. & 1 & 1 & 60 & 52.65 & 56.04 \\
\hline 18. & 3 & 1 & 60 & 48.84 & 47.44 \\
\hline 19. & 2 & 0.5 & 60 & 52.65 & 50.98 \\
\hline 20. & 2 & 1.5 & 60 & 56.32 & 60.09 \\
\hline 21. & 2 & 1 & 40 & 74.43 & 75.26 \\
\hline 22. & 2 & 1 & 80 & 82.70 & 84.36 \\
\hline 23. & 2 & 1 & 60 & 78.77 & 80.73 \\
\hline
\end{tabular}

\section{Results and discussion}

Table S3. Results for the adsorption capacities of lignin tannic acid, non-modified cellulose filter papir for $\mathrm{Ni}^{2+}, \mathrm{Pb}^{2+}$ and $\mathrm{Cr}(\mathrm{VI})$

\begin{tabular}{lccc}
\hline & \multicolumn{3}{c}{ Adsorbent capacity $\left(\mathrm{mg} \mathrm{g}^{-1}\right)$} \\
\hline Adsorbent/ion & $\mathrm{Ni}^{2+}$ & $\mathrm{Pb}^{2+}$ & $\mathrm{Cr}(\mathrm{VI})$ \\
\hline Lignin (Demirbas, 2004; Demirbaş, 2005; Guo et al., 2008) & $0.110^{*}$ & 9.0 & 9.3 \\
Tannic acid** & 5.9 & 8.7 & 7.9 \\
Non-modified Cellulose (Musyoka et al., 2011; Shukla and & 3.37 & $0.0179^{*}$ & $3.03^{* * * *}$ \\
Pai, 2005; Yao et al., 2017) & & & \\
*mmol/g;**results from this study obtained at pH 6; Low adosrption capacities arises from low \\
dispersibility/solubility of the Lignin and Tanninc acid at pH 6, and even pH increase to 8 do not contribute \\
significantly to capacity increase; *** Lignocellulosic material from eucalyptus.
\end{tabular}


Table S4. Hydroxyl and carboxyl groups content $\left(\mathrm{mmol} \mathrm{g}^{-1}\right)$ in non-modified kraft lignin

\begin{tabular}{lc}
\hline Functional groups & Content $\left(\mathrm{mmol} \mathrm{g}^{-}\right.$ \\
& $1)$ \\
\hline $\mathrm{OH}$, total & 5.67 \\
$\mathrm{OH}$, phenolic & 3.21 \\
$\mathrm{COOH}$ & 0.44 \\
$\mathrm{OH}$, aliphatic & 2.46 \\
\hline
\end{tabular}

\subsection{Design of adsorption performances using RSM methodology}

The statistical data of the pore size diameters and overall surface porosity of the Cell-EL and Cell-EL-TA membranes were obtained using Software Image-Pro Plus 6.0 and the results are presented in Table S5:

Table S5. Statistical data represented with mean values

\begin{tabular}{ccc}
\hline Pore characteristics & Cell-EL & Cell-EL-TA \\
\hline Mean fiber diameter, $\mu \mathrm{m}$ & 10.1 & 9.4 \\
Porosity & 48 & 44 \\
\hline
\end{tabular}

\subsection{Characterization of the adsorbent}

\subsubsection{FTIR spectroscopy}

The peak at $3341 \mathrm{~cm}^{-1}$ (Fig. 5a and 5b) is assigned to intra-molecular $\mathrm{O}(3) \mathrm{H}---\mathrm{O}(5), \mathrm{O}(2) \mathrm{H}--$ $-\mathrm{O}(6)$ or $\mathrm{O}(2) \mathrm{H}---\mathrm{O}(6)$ vibrations of hydroxyl group in cellulose I and aliphatic hydroxyl groups in lignin (Popescu et al., 2011). The peak at $3277 \mathrm{~cm}^{-1}$ is characteristic for stretching vibration of hydroxyl and phenolic $\mathrm{O}-\mathrm{H}$ group originated from cellulose materials, lignin and tannic acid (Bykov, 2008; Chung et al., 2004). This peak is overlapped with band assigned to $\mathrm{N}-\mathrm{H}$ stretching vibration of primary and secondary amines, resulting from modification of cellulose with diethylenetriamine (DETA). After the modification of cellulose with glymo silane, the bands at 3076-3006 $\mathrm{cm}^{-1}$ are observed, which belong to stretch vibration of $=\mathrm{C}-\mathrm{H}$ group (Fig. 5a). With further modification, those peaks are probably shifted and overlapped with the peak for methyl and methylene groups. The bands at 2931-2860 $\mathrm{cm}^{-1}$ (Fig. 5a) and 2939-2829 $\mathrm{cm}^{-1}$ (Fig. 5b) indicated on the appearance of asymmetric and symmetric methyl ($\left.\mathrm{CH}_{3}\right)$ and methylene $\left(-\mathrm{CH}_{2}\right) \mathrm{C}-\mathrm{H}$ group in cellulose, modified cellulose and lignin respectively (Chung et al., 2004). The intensity of those peaks after additional modification with epoxy lignin and tannic acid is shifted towards higher wavenumber at $2962-2873 \mathrm{~cm}^{-1}$ (Fig. 5b). The 
assignations at $\sim 2860 \mathrm{~cm}^{-1}$ and $\sim 2873 \mathrm{~cm}^{-1}$ also belong to stretching vibration of methoxy ($\mathrm{OCH}_{3}$ ) group from CPC, and Glymo. In the spectra of lignin, the band at $1692 \mathrm{~cm}^{-1}$ (Fig. 5b) is attributed to $\mathrm{C}=\mathrm{O}$ stretch vibration of the carbonyl group (Bykov, 2008). The band at 1615 $\mathrm{cm}^{-1}$ belong to aromatic $\mathrm{C}=\mathrm{C}$ in tannic acid. The peak at $1595 \mathrm{~cm}^{-1}$ corresponds to vibrations in the aromatic ring of lignin plus $\mathrm{C}=\mathrm{O}$ stretching. The band at $1595 \mathrm{~cm}^{-1}$ broadens to about $1615 \mathrm{~cm}^{-1}$ suggests that there was an increase of structural diversity around the aromatic rings, absorbing at a greater range of frequencies (Esteves et al., 2013). The band at $1428 \mathrm{~cm}^{-1}$ (Fig. 5a) and peaks at 1314, 1205, 1163, 1104 and $1030 \mathrm{~cm}^{-1}$ (Fig. 5a and Fig. 5b) corresponded to $\mathrm{C}-\mathrm{H}$ vibration in-plane, bending of methyl and guaicyl ring of lignin, symmetric and asymmetric stretching of the $\mathrm{C}-\mathrm{O}-\mathrm{C}$ glycoside, $\mathrm{C}-\mathrm{C}$ bending and $\mathrm{C}-\mathrm{O}$ stretching and deformation vibration in cellulose, modified cellulose, lignin and tannic acid (Bykov, 2008; Chung et al., 2004). After modification of cellulose with glymo-silane, the peaks detected at 1104 and $\sim 1030 \mathrm{~cm}^{-1}$ were characteristic bands of the stretch vibration of Si-O-C linkage and $\mathrm{Si}-\mathrm{O}-\mathrm{Si}$, obtained by the formation of covalent bond/hydrogen bond between silane and hydroxyl moieties in cellulose (Qua et al., 2011). The peaks at $895 \mathrm{~cm}^{-1}$ (Fig. 5a) and $854 \mathrm{~cm}^{-}$ ${ }^{1}$ (Fig. 5a) are associated to rocking vibration of $\mathrm{C}-\mathrm{H}$ and $\beta$-glycosidic linkages in cellulose.

(Xu et al., 2013). The peak at $850 \mathrm{~cm}^{-1}$ (Fig. 5a) is attributed to stretching vibration of $-\mathrm{S}-\mathrm{CH}_{3}$ group from Glymo (Qua et al., 2011).

\subsection{Adsorption study}

\subsubsection{Influence of $p H$}

Analysis of the $\mathrm{pH}$ dependent forms of metal ions is very important due to the fact as it influences properties, mobility/diffusibility, reactivity and extent/type of interaction with adsorbent surface functionality. In order to understand adsorption processes, a few operational parameter and system components properties such as: the solubility/speciation of metal ions, concentration and properties of counter adsorbate ions, type and degree of the ionization of adsorbent functional groups i.e. protonation/deprotonation of the adsorbent functional groups, interaction/reaction of surface groups with electrolyte ions/water and $\mathrm{pH}$ value change in the course of adsorption must be investigated. $\mathrm{pH}$ of solution and $\mathrm{pH}$ change are important parameter to be investigated. Hence, the influences of initial $\mathrm{pH}\left(\mathrm{pH}_{\mathrm{i}}\right)$ on the effectiveness of ions removal was studied. The obtained results on ions removal (in \%) versus $\mathrm{pH}$ with $\mathrm{pH}$ dependent precipitation of heavily soluble salts are presented in Fig. S3. Taking into consideration the $\mathrm{Ni}^{2+}$ and $\mathrm{Pb}^{2+}$ ions hydrolysis (Fig S2), obtained using MINTEQ 3.0 software, 
high removal efficiency was expected at neutral and basic solutions. At $\mathrm{pH}<\mathrm{pH}$ PzC, competitiveness of cation and proton result in lower adsorption efficiency, while at $\mathrm{pH}>\mathrm{pH} P \mathrm{PZC}$, i.e. $\mathrm{pH} 6.0$ and 7.0, increasing negative potential at adosrbent surface, i.e. increased attraction with cation, presence of partially hydrolized ionic species, $\mathrm{Pb}(\mathrm{OH})^{+}$and $\mathrm{Ni}(\mathrm{OH})^{+}$, and precipitated $\mathrm{Pb}(\mathrm{OH})_{2}$ and $\mathrm{Ni}(\mathrm{OH})_{2}$ (Fig. S2), contribute to increase of removal efficiency up to pH 12 (Fig. S3). Thus, couple adsorption mechanism, participation of physisorption and chemisortion with precipitation, contributes to overall cation removal in the $\mathrm{pH}$ region from 6 to 12 at different extent. At $\mathrm{pH}<\mathrm{pH}$ PZC, the effective electrostatic attraction of negatively charged $\mathrm{HCrO}_{4}{ }^{-} / \mathrm{CrO}_{4}{ }^{2-}$ species with positively charged adsorbent surface (Fig. S2) is the main adsorption mechanism at this condition. At $\mathrm{pH}>\mathrm{pH} P \mathrm{PC}$ electrostatic repulsion cause a dominance of a repulsion, i.e. lower adsorption is a consequence. The selected $\mathrm{pH}$ for metal ions removal is justified where no interference with hydrolyzed and other heavily soluble precipitates (carbonate, sulfate etc.) exist.
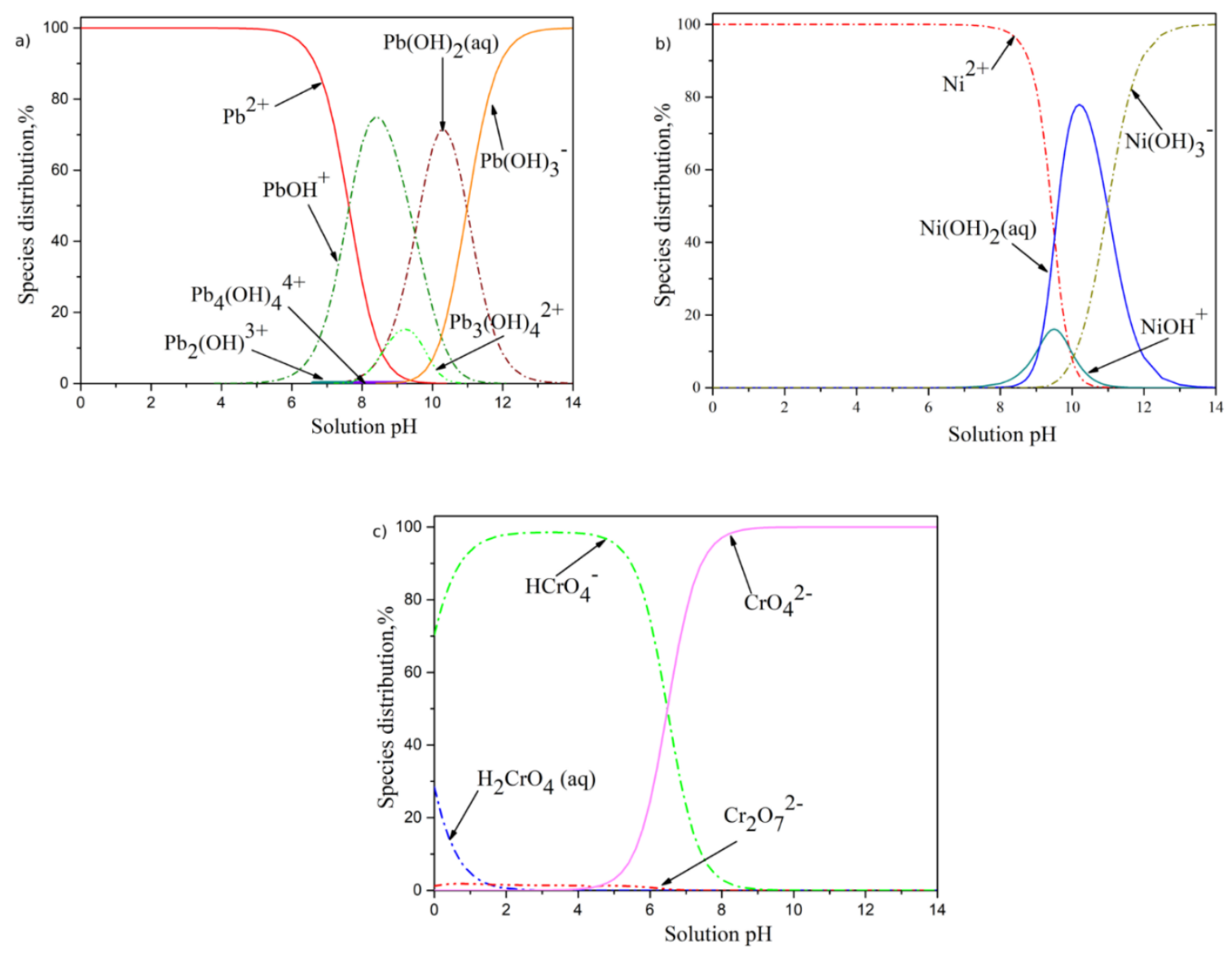

Fig. S2. Speciation of (a) $\mathrm{Pb}^{2+}$, (b) $\mathrm{Ni}^{2+}$ and (c) $\mathrm{Cr}(\mathrm{VI})$ obtained using MINTEQ 3.0 software $\left(C_{\mathrm{i}}=1 \mathrm{mg} \mathrm{dm}^{-3}\right.$ for $\mathrm{Pb}^{2+}, \mathrm{Ni}^{2+}$ and $\left.\mathrm{Cr}(\mathrm{VI}), t=25^{\circ} \mathrm{C}\right)$ 

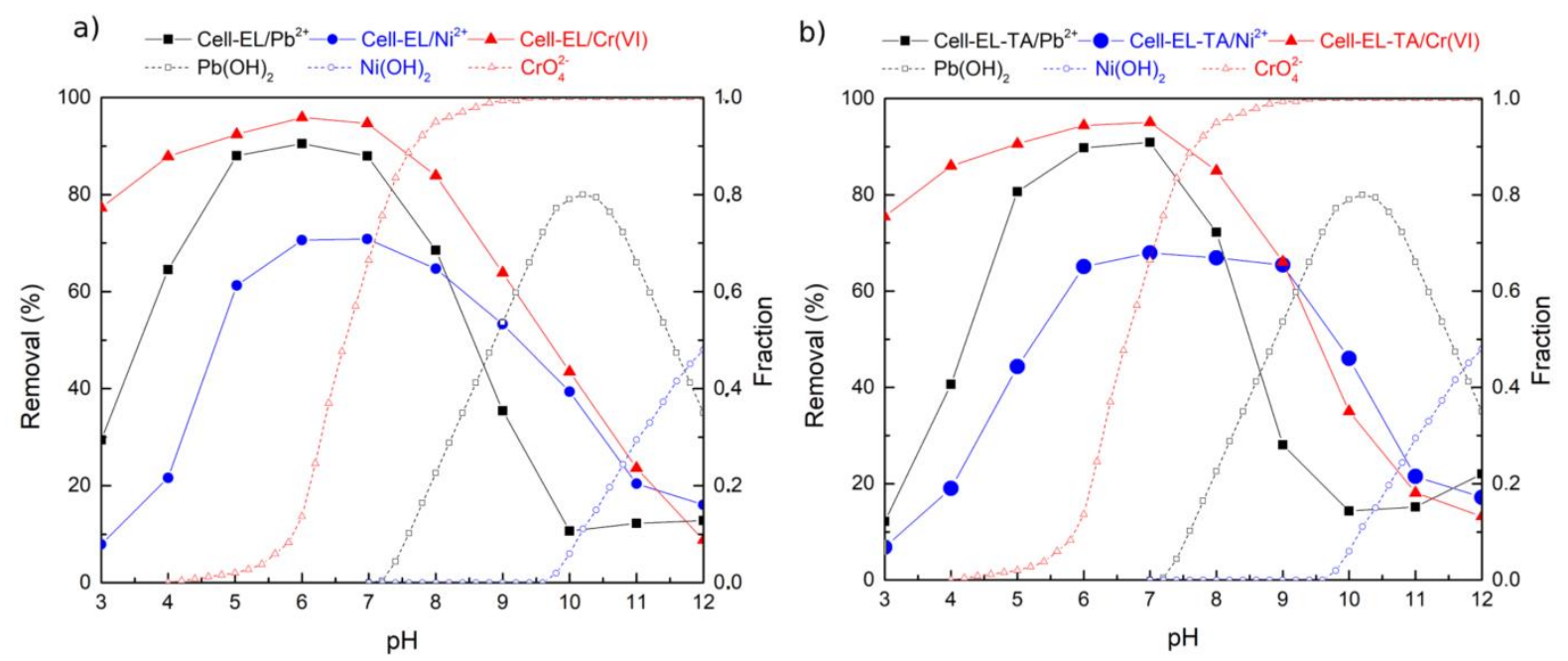

Fig. S3. Influence of $\mathrm{pH}$ on $\mathrm{Ni}^{2+}, \mathrm{Pb}^{2+}$ and $\mathrm{Cr}(\mathrm{VI})$ removal by Cell-EL-TA $\left(C_{\mathrm{i}}=10.5,11.00\right.$ and $12.00 \mathrm{mg} \mathrm{dm}^{-3}$ for $\mathrm{Ni}^{2+}, \mathrm{Pb}^{2+}$ and $\mathrm{Cr}(\mathrm{VI})$ respectively, $m / V=1250 \mathrm{mg} \mathrm{dm}^{-3}, \mathrm{~T}=25^{\circ} \mathrm{C}$ )

\subsubsection{Adsorption isotherms}

In this work, the equilibrium adsorption data were fitted into the following isotherm models: Langmuir, Freundlich, Temkin and Dubinin-Radushkevich.

The Langmuir empirical model (Eq. S10) assumes monolayer adsorption on a homogeneous surface where all sorption sites are found to be identical and energetically equivalent. The Freundlich model (Eq. S11) can be applied to multilayer adsorption on a heterogeneous adsorbent surface with a non-uniform distribution of adsorption heat (Foo and Hameed, 2010).

$q_{e}=\frac{q_{m} K_{L} C_{e}}{1+K_{L} C_{e}}$ or linear form $\frac{C_{e}}{q_{e}}=\frac{1}{K_{L} q_{m}}+\frac{C_{e}}{q_{m}}$

$q_{e}=K_{F} C_{e}^{\frac{1}{n}}$ or linear form $\log q_{e}=\log K_{F}+\frac{1}{n} \log C_{e}$

where $C_{e}$ is adsorbate concentration at equilibrium $\left(\mathrm{mg} \mathrm{dm}^{-3}\right) ; q_{e}$ is the adsorption capacity at equilibrium $\left(\mathrm{mg} \mathrm{g}^{-1}\right) ; q_{\mathrm{m}}$ is the maximum adsorption capacity $\left(\mathrm{mg} \mathrm{g}^{-1}\right)$ and $K_{L}$ is the Langmuir isotherm constant $\left(\mathrm{dm}^{3} \mathrm{mg}^{-1}\right)$;

The $K_{L}$ constant, from Eq. S10, can be used to calculate a dimensionless equilibrium parameter $\left(\mathrm{R}_{\mathrm{L}}\right)$ by the following equation:

$$
R_{L}=\frac{1}{1+K_{L} \cdot C_{i}}
$$


where $C_{i}$ is the highest initial pollutant concentration. The value of $\mathrm{R}_{\mathrm{L}}$ indicates the adsorption nature to be either unfavorable $\left(\mathrm{R}_{\mathrm{L}}>1\right)$, linear $\left(\mathrm{R}_{\mathrm{L}}=1\right)$, favorable $\left(0<\mathrm{R}_{\mathrm{L}}<1\right)$ or irreversible $\left(\mathrm{R}_{\mathrm{L}}\right.$ $=0)$.

From the Freundlich equation (Eq. S11) $K_{F}\left(\mathrm{~mol}^{1-n} \mathrm{~L}^{n} / \mathrm{g}\right)$ and $\mathrm{n}$ are the Freundlich constants and represent adsorption capacity and adsorption strength, respectively.

The Dubinine-Radushkevic (D-R) isotherm model was used in order to determine if the adsorption occurred by a physical or chemical process. The linear form of this model is expressed by Eq. (S13):

$\ln q_{e}=\ln q_{m}-B(R T)^{2}\left[\ln \left(1+\frac{1}{C_{e}}\right)\right]^{2}$

where $B\left(\mathrm{~mol}^{2} \mathrm{~kJ}^{-2}\right)$ and $q_{m}\left(\mathrm{mg} \mathrm{g}^{-1}\right)$ are D-R constants which are calculated from the slope of $\ln q_{e}$ versus $[R T \ln (1+1 / C e)]^{2}$ and intercept.

The Temkin isotherm model implies a uniform distribution of binding energies onto the adsorbent surface and is described by Eq. (S14) (Foo and Hameed, 2010; Karanac et al., 2018) $q_{e}=\frac{R T}{b} \ln \left(A C_{e}\right)$ or linear form $q_{e}=\frac{R T}{b} \ln A+\frac{R T}{b} \ln C_{e}$

Where the $A$ is the Temkin isotherm equilibrium constant $\left(\mathrm{dm}^{3} \mathrm{~g}^{-1}\right)$ and $b$ is Temkin isotherm constant related to the heat of adsorption.

Table S6. Non-linear Freundlich, Temkin and Dubinin-Radushkevich isotherm parameters for $\mathrm{Ni}^{2+}$ adsorption on Cell-EL

\begin{tabular}{cllll}
\hline & & $25^{\circ} \mathrm{C}$ & $35^{\circ} \mathrm{C}$ & $45^{\circ} \mathrm{C}$ \\
\cline { 2 - 5 } Freundlich & $K_{\mathrm{F}}\left(\mathrm{mg} \mathrm{g}^{-1}\right)\left(\mathrm{dm}^{3} \mathrm{mg}^{-1}\right)^{1 / \mathrm{n}}$ & 13.499 & 14.678 & 16.032 \\
isotherm & $1 / n$ & 0.702 & 0.703 & 0.706 \\
& $R^{2}$ & 0.980 & 0.984 & 0.987 \\
\cline { 2 - 5 } & $A_{\mathrm{T}}\left(\mathrm{dm}^{3} \mathrm{~g}^{-1}\right)$ & 3.793 & 4.024 & 4.287 \\
Temkin & $b_{T}$ & 201.97 & 199.28 & 196.18 \\
isotherm & $B\left(\mathrm{~J} \mathrm{~mol}^{-1}\right)$ & 12.27 & 12.86 & 13.48 \\
& $R^{2}$ & 0.976 & 0.972 & 0.965 \\
\cline { 2 - 5 } & $q_{\mathrm{m}}\left(\mathrm{mg} \mathrm{g}^{-1}\right)$ & 27.75 & 28.99 & 30.24 \\
Dubinin- & $K_{a d}\left(\mathrm{~mol}^{2} \mathrm{KJ}^{-2}\right)$ & 7.660 & 7.610 & 7.570 \\
Radushkevich & $E_{a}\left(\mathrm{KJmol}^{-1}\right)$ & 8.071 & 8.104 & 8.127 \\
isotherm & $R^{2}$ & 0.890 & 0.886 & 0.882 \\
\hline
\end{tabular}

Table S7. Non-linear Freundlich, Temkin and Dubinin-Radushkevich isotherm parameters for $\mathrm{Ni}^{2+}$ adsorption on Cell-EL-TA 


\begin{tabular}{cllll}
\hline & & $25{ }^{\circ} \mathrm{C}$ & $35^{\circ} \mathrm{C}$ & $45^{\circ} \mathrm{C}$ \\
\cline { 2 - 5 } Freundlich & $K_{\mathrm{F}}\left(\mathrm{mg} \mathrm{g}^{-1}\right)\left(\mathrm{dm}^{3} \mathrm{mg}^{-1}\right)^{1 / n}$ & 15.657 & 16.614 & 17.644 \\
isotherm & $1 / n$ & 0.778 & 0.775 & 0.771 \\
& $R^{2}$ & 0.993 & 0.994 & 0.995 \\
\cline { 2 - 5 } & $A_{\mathrm{T}}\left(\mathrm{dm}^{3} \mathrm{~g}^{-1}\right)$ & 3.618 & 3.802 & 4.017 \\
Temkin & $b_{T}$ & 162.7 & 164.36 & 166.33 \\
isotherm & $B\left(\mathrm{~J} \mathrm{~mol}^{-1}\right)$ & 15.24 & 15.59 & 15.90 \\
& $R^{2}$ & 0.950 & 0.945 & 0.938 \\
\cline { 2 - 5 } Dubinin- & $q_{\mathrm{m}}\left(\mathrm{mg} \mathrm{g}^{-1}\right)$ & 31.54 & 31.97 & 32.34 \\
Radushkevich & $K_{a d}\left(\mathrm{~mol}^{2} \mathrm{KJ}^{-2}\right)$ & 7.53 & 7.52 & 7.50 \\
isotherm & $E_{a}\left(\mathrm{KJmol}^{-1}\right)$ & 8.149 & 8.157 & 8.163 \\
& $R^{2}$ & 0.879 & 0.867 & 0.854 \\
\hline
\end{tabular}

Table S8. Non-linear Freundlich, Temkin and Dubinin-Radushkevich isotherm parameters for $\mathrm{Pb}^{2+}$ adsorption on Cell-EL

\begin{tabular}{cllll}
\hline & & $25{ }^{\circ} \mathrm{C}$ & $35^{\circ} \mathrm{C}$ & $45^{\circ} \mathrm{C}$ \\
\cline { 2 - 5 } Freundlich & $K_{\mathrm{F}}\left(\mathrm{mg} \mathrm{g}^{-1}\right)\left(\mathrm{dm}^{3} \mathrm{mg}^{-1}\right)^{1 / \mathrm{n}}$ & 36.411 & 38.277 & 40.339 \\
isotherm & $1 / n$ & 0.648 & 0.656 & 0.663 \\
& $R^{2}$ & 0.994 & 0.991 & 0.986 \\
\cline { 2 - 5 } & $A_{\mathrm{T}}\left(\mathrm{dm}^{3} \mathrm{~g}^{-1}\right)$ & 10.727 & 11.033 & 11.399 \\
Temkin & $b_{T}$ & 142.54 & 143.35 & 144.07 \\
isotherm & $B\left(\mathrm{~J} \mathrm{~mol}^{-1}\right)$ & 17.39 & 17.87 & 18.36 \\
& $R^{2}$ & 0.938 & 0.948 & 0.958 \\
\cline { 2 - 5 } Dubinin- & $q_{\mathrm{m}}\left(\mathrm{mg} \mathrm{g}^{-1}\right)$ & 43.64 & 45.88 & 48.43 \\
Radushkevich & $K_{a d}\left(\mathrm{~mol}^{2} \mathrm{KJ}^{-2}\right)$ & 8.470 & 8.420 & 8.360 \\
isotherm & $E_{a}\left(\mathrm{KJmol}^{-1}\right)$ & 7.685 & 7.708 & 7.733 \\
& $R^{2}$ & 0.876 & 0.895 & 0.915 \\
\hline
\end{tabular}

Table S9. Non-linear Freundlich, Temkin and Dubinin-Radushkevich isotherm parameters for $\mathrm{Pb}^{2+}$ adsorption on Cell-EL-TA

\begin{tabular}{cllll}
\hline & & $25^{\circ} \mathrm{C}$ & $35^{\circ} \mathrm{C}$ & $45{ }^{\circ} \mathrm{C}$ \\
\cline { 2 - 5 } Freundlich & $K_{\mathrm{F}}\left(\mathrm{mg} \mathrm{g}^{-1}\right)\left(\mathrm{dm}^{3} \mathrm{mg}^{-1}\right)^{1 / \mathrm{n}}$ & 36.788 & 40.849 & 45.887 \\
isotherm & $1 / n$ & 0.671 & 0.684 & 0.697 \\
& $R^{2}$ & 0.998 & 0.999 & 0.999 \\
\cline { 2 - 5 } Temkin & $A_{\mathrm{T}}\left(\mathrm{dm}^{3} \mathrm{~g}^{-1}\right)$ & 10.068 & 10.896 & 11.973 \\
isotherm & $b_{T}$ & 137.05 & 135.35 & 133.72 \\
& $B\left(\mathrm{~J} \mathrm{~mol}^{-1}\right)$ & 18.09 & 18.93 & 19.78 \\
& $R^{2}$ & 0.917 & 0.917 & 0.917 \\
\cline { 2 - 5 } Dubinin- & $q_{\mathrm{m}}\left(\mathrm{mg} \mathrm{g}^{-1}\right)$ & 43.35 & 46.15 & 49.43 \\
Radushkevich & $K_{a d}\left(\mathrm{~mol}^{2} \mathrm{KJ}^{-2}\right)$ & 8.47 & 8.41 & 8.34 \\
isotherm & $E_{a}\left(\mathrm{KJmol}^{-1}\right)$ & 7.682 & 7.711 & 7.742 \\
& $R^{2}$ & 0.861 & 0.878 & 0.897 \\
\hline
\end{tabular}

Table S10. Non-linear Freundlich, Temkin and Dubinin-Radushkevich isotherm parameters for $\mathrm{Cr}(\mathrm{VI})$ adsorption on Cell-EL 


\begin{tabular}{cllll}
\hline \multirow{2}{*}{ Freundlich } & $K_{\mathrm{F}}\left(\mathrm{mg} \mathrm{g}^{-1}\right)\left(\mathrm{dm}^{3} \mathrm{mg}^{-1}\right)^{1 / \mathrm{n}}$ & 68.106 & 69.502 & 70.875 \\
isotherm & $1 / n$ & 0.642 & 0.637 & 0.630 \\
& $R^{2}$ & 0.992 & 0.996 & 0.996 \\
\cline { 2 - 5 } & $A_{\mathrm{T}}\left(\mathrm{dm}^{3} \mathrm{~g}^{-1}\right)$ & 21.787 & 23.155 & 24.807 \\
Temkin & $b_{T}$ & 116.99 & 122.04 & 127.54 \\
isotherm & $B\left(\mathrm{~J} \mathrm{~mol}^{-1}\right)$ & 21.19 & 20.99 & 20.74 \\
& $R^{2}$ & 0.944 & 0.930 & 0.913 \\
\cline { 2 - 5 } Dubinin- & $q_{\mathrm{m}}\left(\mathrm{mg} \mathrm{g}^{-1}\right)$ & 62.45 & 61.83 & 61.23 \\
Radushkevich & $K_{a d}\left(\mathrm{~mol}^{2} \mathrm{KJ}^{-2}\right)$ & 6.72 & 6.73 & 6.74 \\
isotherm & $E_{a}\left(\mathrm{KJmol}^{-1}\right)$ & 8.622 & 8.616 & 8.610 \\
& $R^{2}$ & 0.933 & 0.928 & 0.922 \\
\hline
\end{tabular}

Table S11. Non-linear Freundlich, Temkin and Dubinin-Radushkevich isotherm parameters for $\mathrm{Cr}(\mathrm{VI})$ adsorption on Cell-EL-TA

\begin{tabular}{cllll}
\hline & & $25^{\circ} \mathrm{C}$ & $35^{\circ} \mathrm{C}$ & $45^{\circ} \mathrm{C}$ \\
\cline { 2 - 5 } Freundlich & $K_{\mathrm{F}}\left(\mathrm{mg} \mathrm{g}^{-1}\right)\left(\mathrm{dm}^{3} \mathrm{mg}^{-1}\right)^{1 / \mathrm{n}}$ & 78.395 & 79.878 & 81.270 \\
isotherm & $1 / n$ & 0.648 & 0.642 & 0.635 \\
& $R^{2}$ & 0.992 & 0.996 & 0.997 \\
\cline { 2 - 5 } Temkin & $A_{\mathrm{T}}\left(\mathrm{dm}^{3} \mathrm{~g}^{-1}\right)$ & 25.569 & 27.193 & 29.172 \\
isotherm & $b_{T}$ & 113.08 & 118.13 & 123.69 \\
& $B\left(\mathrm{~J} \mathrm{~mol}^{-1}\right)$ & 21.92 & 21.69 & 21.39 \\
& $R^{2}$ & 0.941 & 0.928 & 0.911 \\
\cline { 2 - 4 } Dubinin- & $q_{\mathrm{m}}\left(\mathrm{mg} \mathrm{g}^{-1}\right)$ & 66.55 & 65.82 & 65.09 \\
Radushkevich & $K_{a d}\left(\mathrm{~mol}^{2} \mathrm{KJ}^{-2}\right)$ & 6.66 & 6.67 & 6.68 \\
isotherm & $E_{a}\left(\mathrm{KJmol}^{-1}\right)$ & 8.664 & 8.657 & 8.649 \\
& $R^{2}$ & 0.941 & 0.936 & 0.930 \\
\hline
\end{tabular}

\subsubsection{Thermodynamic parameters of adsorption}

Thermodynamic factors enable in estimating the feasibility, energy change and randomness before and after the adsorbate/adsorbent interactions. Gibbs free energy $\left(\Delta G^{0}\right)$, enthalpy $\left(\Delta H^{\Theta}\right)$ and entropy $\left(\Delta S^{\Theta}\right)$ calculated from Van't Hoff equation were used as indicators of the possible nature of adsorption process Eq. (S15) and (S16) (Lombardo and Thielemans, 2019):

$$
\begin{aligned}
& \Delta G^{\Theta}=-R T \ln \left(K_{L}\right) \\
& \ln \left(K_{L}\right)=\frac{\Delta S^{\Theta}}{R}-\frac{\Delta H^{\Theta}}{(R T)}
\end{aligned}
$$

where $T$ is the absolute temperature $(\mathrm{K})$, and $R$ is the universal gas constant $\left(\mathrm{J} \mathrm{mol}^{-1} \mathrm{~K}^{-1}\right)$. Langmuir adsorption constant $K_{L}$ is obtained from isothermal experiments. $\Delta H^{\Theta}$ and $\Delta S^{\Theta}$ are 
calculated from slopes and interceptions in diagram $\ln \left(K_{L}\right)-T^{-1}$, with a premise that the system attained stationary conditions.

\subsubsection{Adsorption kinetics}

Kinetic studies provide information about optimum conditions, mechanism of sorption, and possible rate-controlling step. For this aim, pseudo-first and pseudo-second-order kinetics is applied on experimental adsorption data. These models represent adsorption reaction models.

The pseudo-first order equation (Lagergren rate equation) generalizes the physical interactions between the adsorbent and adsorbate molecules. The linear form pseudo-first order equation is expressed by Eq. (S17) (Moussout et al., 2018; Qiu et al., 2009):

$\ln \left(q_{e}-q_{t}\right)=\ln q_{e}-k_{1} t$

where $q_{t}\left(\mathrm{mg} \mathrm{g}^{-1}\right)$ represent the amount of adsorbate adsorbed per unit weight of the adsorbent, $q_{e}\left(\mathrm{mg} \mathrm{g}^{-1}\right)$ is the adsorption capacity at equilibrium, $k_{l}\left(\mathrm{~min}^{-1}\right)$ is the pseudo-first order rate constant of adsorption process and $t(\mathrm{~min})$ is the contact time.

Pseudo-second order kinetic model indicates the favourable chemical interactions between the adsorbent and adsorbate.The linear form of pseudo-second order model is given by Eq. (S18) (Ren et al., 2011):

$\frac{t}{q_{t}}=\frac{1}{k_{2} q_{e}^{2}}+\frac{1}{q_{e}}$

where $k_{2}\left(\mathrm{~g} \mathrm{mg}^{-1} \mathrm{~min}^{-1}\right)$ is the pseudo-second order rate constant of the adsorption process, $q_{t}$ $\left(\mathrm{mg} \mathrm{g}^{-1}\right)$ and $q_{e}\left(\mathrm{mg} \mathrm{g}^{-1}\right)$ are the adsorption capacities at time $\mathrm{t}$ and at equilibrium. The initial adsorption rate, $h_{2}\left(\mathrm{mg} \mathrm{g}^{-1} \mathrm{~min}^{-1}\right)$ at $\mathrm{t} \rightarrow 0$ is defined as Eq. (S19):

$h_{2}=k_{2} q_{e}^{2}$

The $h_{2}, q_{\mathrm{e}}$ and $k_{2}$ can be obtained by linear plot of $t / q_{t}$ versus $t$.

The other group of mathematical models that have been proposed to describe adsorption data, can generally be classified as adsorption diffusion models. Adsorption diffusion models are consisted of three consecutive steps: (1) diffusion across the liquid film

surrounding the adsorbent particles, i.e., external diffusion or film diffusion; (2) diffusion in the liquid contained in the pores and/or along the pore walls, which is so-called internal diffusion or intra-particle diffusion; and (3) adsorption and desorption between the adsorbate and active sites, i.e., mass action. The intraparticle diffusion model established on the theory proposed by Weber and Morris: Weber-Morris model can be used when intraparticle diffusion is the only rate-limiting step (Qiu et al., 2009; Soldatkina and Zavrichko, 2018): 
$q_{t}=k_{i} t^{\frac{1}{2}}+C_{B L}$

where $k_{i}\left(\mathrm{mg} \mathrm{g}^{-1} \min ^{1 / 2}\right)$ is intraparticle diffusion rate constant and $C_{B L}$ is constant which reflects the boundary layer effect. In Weber-Morris model if the intraparticle diffusion is the only ratelimiting step, then the graph of $q_{t} v s . t^{1 / 2}$ is a streight line and pass through the origin. The values $C_{B L}$ and $k_{i}$ can be calculated from the intercept and slope of $q_{t} \mathrm{vs} . t^{1 / 2}$ plot.

Dunwald-Wagner proposed another model to describe intraparticle diffusion. D-W relation could be expressed by Eq. (S21) and (S22):

$\frac{q_{t}}{q_{e}}=1-\frac{6}{\pi^{2}} \sum_{n=1}^{\infty} \frac{1}{n^{2}} \exp \left[-n^{2} K t\right]$

where $K\left(\mathrm{~min}^{-1}\right)$ is the rate constant of adsorption. Simplification of the Eq. (S21) gave:

$\log \left(1-\left(\frac{q_{t}}{q_{e}}\right)^{2}\right)=-\frac{K}{2.303} t$

A plot of $\log \left(1-\left(q / q_{t}\right)^{2}\right) v s t$ should give linear plot and the rate constant can be calculated from the slope of correlation line. D-W was rationally used to describe various types of adsorption systems and estimation of adsorption kinetics. Serin and Ellickson expressed the D-W equation in terms of the partial completion of the reaction Eq. (S23) (Serin and Ellickson, 1941):

$k_{D W} t=\frac{\pi^{2}}{r^{2}} D t=\ln \frac{6}{\pi^{2}(1-\alpha)}=-\log \left(1-\left(\frac{q_{t}}{q_{e}}\right)^{2}\right)$

where $D$ is the diffusion coefficient of the migrating species and $k_{\mathrm{DW}}$ is the Dunwald-Wagner isothermal reaction constant, $r$ is the initial radius of the reacting particle, $\alpha$ is the fractional completion of reactions at time $t, q_{\mathrm{e}}$ and $q_{\mathrm{t}}$ are the adsorption capacity of adsorbent $\left(\mathrm{mg} \mathrm{g}^{-1}\right)$ at equilibrium and appropriate $t$, respectively.

Homogeneous solid diffusion model (HSDM) is a typical intra-particle diffusion model which can describe mass transfer in an amorphous and homogeneous sphere. HSDM model can be expressed by differential equation (Qiu et al., 2009; Viegas et al., 2014):

$$
\frac{\partial q}{\partial t}=\frac{D_{s}}{r^{2}} \frac{\partial}{\partial r}=\left(r^{2} \frac{\partial q}{\partial r}\right)
$$

where $D$ s is intraparticle diffusion coefficient, $r$ radial position, and $q$ the time-dependent adsorption capacity. The precisely solution to Eq. (S25) for the defined adsorption condition was given by Crank :

$$
\frac{q_{t}}{q_{e}}=1+\frac{2 R}{\pi r} \sum_{n=1}^{\infty} \frac{(-1)^{n}}{n} \sin \frac{n \pi r}{R} \exp \left[\frac{-D_{s} t \pi^{2} n^{2}}{R^{2}}\right]
$$


The equation discussed above is generally somewhat valid in a short time.

The value of $D$ s for long-time data can be also determined by plotting of $\ln \left(1-q_{t} / q_{\mathrm{e}}\right) v s t$.

$\ln \left(1-\frac{q_{t}}{q_{e}}\right)=\frac{-D_{S} \pi^{2}}{R^{2}} t+\ln \frac{3}{\pi^{2}}$

The Eq. (S26) refers to the change rate of surface concentration $q_{t}$ with time $t$ at any distance $R$ from the center of adsorbent particle during adsorption for a constant boundary condition and developed a nonlinear equation for the total mass of adsorbate present on the surface of a unit weight of adsorbent $q_{t}$ for a particular contact time $t$. In case there is none film diffusion limitation, this equation can be generalized into a non-dimensional. The homogeneous solid diffusion model equations are solved numerically, for a single solute with uniform adsorbent size.

\subsection{Regeneration and effluent water purification}

In order to evaluate regeneration capabilities of synthesized memebranes three adsorption/desorption cycles was performed at following condition: $\left(Q=0.5 \mathrm{~cm}^{3} \mathrm{~min}^{-1}\right.$; $m_{\text {ads }}($ Cell-EL $)=0.4875 \mathrm{~g} ; m_{\text {ads }}($ Cell-EL-TA $)=0.5025 \mathrm{~g} ; C_{\mathrm{i}\left(\mathrm{Ni}^{2+}\right)}=1.05 \mathrm{mg} \mathrm{dm}^{-3} ; C_{\mathrm{i}\left(\mathrm{Pb}^{2+}\right)}=1.1 \mathrm{mg} \mathrm{dm}^{-3}$; $\left.C_{\mathrm{i}(\mathrm{Cr}(\mathrm{VI})}=1.2 \mathrm{mg} \mathrm{dm}^{-3}\right)$ using $1 \% \mathrm{NaOH}$. The obtained results, in relation to adsorption capacity, volume of the feed water at which breakthrough pint is reached, quantity of desorbed material, conentration of the pollutant in effluent water and residual (tightly bonded pollutant) after $\mathrm{i}^{\text {th }}$ adsorption/desorption cycle. 


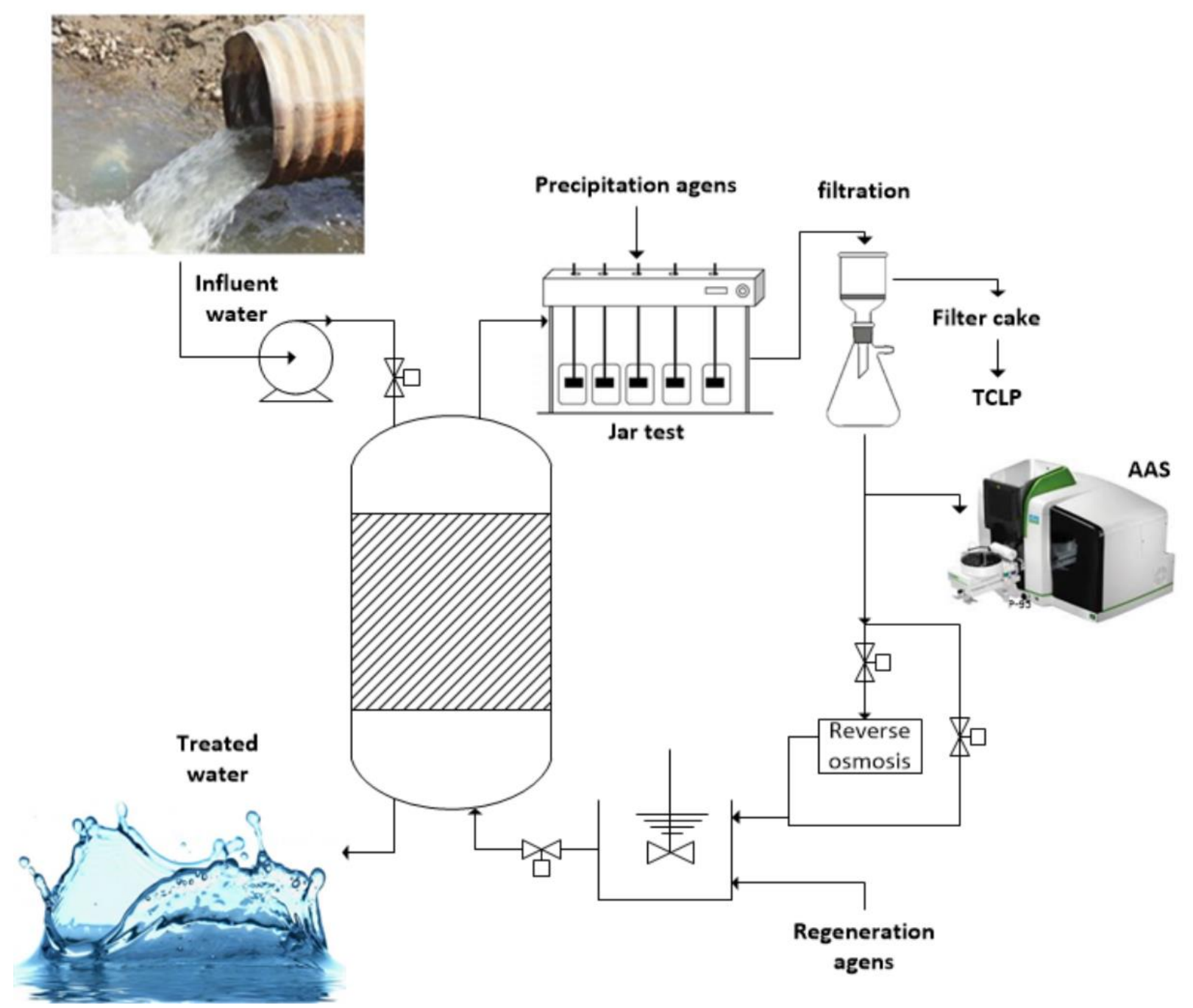

Fig. S4. Schematic illustration of regeneration and effluent water purification 
Table $\mathrm{S} 12$. The results of adsorption-desorption cycles of the $\mathrm{Ni}^{2+}, \mathrm{Pb}^{2+}$ and $\mathrm{Cr}(\mathrm{VI})$ ions and both Cell-EL and Cell-EL-TA system $\left(Q=0.5 \mathrm{~cm}^{3} \mathrm{~min}^{-1} ; m_{\text {ads }}(\right.$ Cell-EL $)=0.4875 \mathrm{~g} ; m_{\text {ads }}($ Cell-EL$\left.\mathrm{TA})=0.5025 \mathrm{~g} ; C_{\mathrm{i}\left(\mathrm{Ni}^{2+}\right)}=1.05 \mathrm{mg} \mathrm{dm}^{-3} ; C_{\mathrm{i}\left(\mathrm{Pb}^{2+}\right)}=1.1 \mathrm{mg} \mathrm{dm}^{-3} ; C_{\mathrm{i}(\mathrm{Cr}(\mathrm{VI})}=1.2 \mathrm{mg} \mathrm{dm}^{-3}\right)$ using $0.5 \%$

\section{$\mathrm{NaOH}$}

\begin{tabular}{|c|c|c|c|c|c|c|c|c|c|}
\hline \multirow{2}{*}{\multicolumn{2}{|c|}{ Adsorbate/cycle }} & \multicolumn{3}{|c|}{ Cell-EL } & \multicolumn{5}{|c|}{ Cell-EL-TA } \\
\hline & & I & II & III & $\mathrm{IV}^{5}$ & $\mathrm{I}$ & II & III & IV \\
\hline \multirow{5}{*}{$\mathrm{Ni}^{2+}$} & Adsorption $^{1}\left(\mathrm{mg} \mathrm{g}^{-1}\right)$ & 29.88 & 27.44 & 24.63 & & 45.12 & 42.82 & 39.92 & \\
\hline & $V^{2}\left(\mathrm{dm}^{3}\right)$ & 13.87 & 12.74 & 11.43 & & 21.59 & 20.49 & 19.10 & \\
\hline & $\operatorname{Desorption}^{1}\left(\mathrm{mg} \mathrm{g}^{-1}\right)$ & 29.22 & 26.42 & 23.59 & & 44.35 & 41.66 & 38.40 & \\
\hline & $C^{3}(\mathrm{ppm})$ & 292.22 & 264.2 & 235.9 & & 443.5 & 416.6 & 384.0 & \\
\hline & $\Delta q^{4}\left(\mathrm{mg} \mathrm{g}^{-1}\right)$ & 0.66 & 1.02 & 1.04 & 2.72 & 0.77 & 1.16 & 1.52 & 3.45 \\
\hline \multirow{5}{*}{$\mathrm{Pb}^{2+}$} & Adsorption $\left(\mathrm{mg} \mathrm{g}^{-1}\right)$ & 43.53 & 41.03 & 38.64 & & 53.56 & 51.06 & 48.66 & \\
\hline & $\mathrm{V}\left(\mathrm{dm}^{3}\right)$ & 19.29 & 18.18 & 17.12 & & 24.47 & 23.32 & 22.23 & \\
\hline & Desorption $\left(\mathrm{mg} \mathrm{g}^{-1}\right)$ & 42.27 & 39.39 & 36.63 & & 52.44 & 49.53 & 46.47 & \\
\hline & $C(\mathrm{ppm})$ & 422.7 & 393.9 & 366.3 & & 524.4 & 495.3 & 464.7 & \\
\hline & $\Delta q\left(\mathrm{mg} \mathrm{g}^{-1}\right)$ & 1.26 & 1.64 & 2.01 & 4.91 & 1.12 & 1.53 & 2.19 & 4.84 \\
\hline \multirow{5}{*}{$\mathrm{Cr}(\mathrm{VI})$} & Adsorption $\left(\mathrm{mg} \mathrm{g}^{-1}\right)$ & 56.42 & 53.81 & 51.92 & & 60.05 & 57.51 & 55.66 & \\
\hline & $\mathrm{V}\left(\mathrm{dm}^{3}\right)$ & 22.92 & 21.86 & 21.09 & & 25.15 & 24.08 & 23.31 & \\
\hline & Desorption $\left(\mathrm{mg} \mathrm{g}^{-1}\right)$ & 55.01 & 51.82 & 49.74 & & 59.45 & 56.24 & 53.82 & \\
\hline & $C(\mathrm{ppm})$ & 550.1 & 518.2 & 497.4 & & 594.5 & 562.4 & 538.2 & \\
\hline & $\Delta q\left(\mathrm{mg} \mathrm{g}^{-1}\right)$ & 1.41 & 1.99 & 2.18 & 5.58 & 0.60 & 1.27 & 1.84 & 3.71 \\
\hline
\end{tabular}

${ }^{1}$ adsorption capacity and quantity of desorbed pollutants; ${ }^{2}$ volume of the feed water until reaching of breakthrough point; ${ }^{3}$ concentration of the pollutant in effluent water in ppm; $\quad{ }^{4}$ quantity of the irreversely bonded pollutants; ${ }^{5} 100 \mathrm{ml}$-volume of desorption solution

\subsubsection{Technologies for effluent water processing}

In order to provide effective removing of dissolved divalent $\mathrm{Pb}^{2+}$ cations from effluent solutions with calcium phosphates, $\beta$ - $\mathrm{Ca}_{3}\left(\mathrm{PO}_{4}\right)_{2}, \mathrm{CaHPO}_{4} \times 2 \mathrm{H}_{2} \mathrm{O}$ and $\mathrm{Ca}\left(\mathrm{H}_{2} \mathrm{PO}_{4}\right)_{2} \times \mathrm{H}_{2} \mathrm{O}$ were tested. The removal of $\mathrm{Pb}^{2+}$ from the aqueous solution was completed by $0.5 \mathrm{~h}$ using $\mathrm{CaHPO}_{4} \times 2 \mathrm{H}_{2} \mathrm{O}$ and $\mathrm{Ca}\left(\mathrm{H}_{2} \mathrm{PO}_{4}\right)_{2} \times \mathrm{H}_{2} \mathrm{O}$ and almost $6 \mathrm{~h}$ by using $\beta-\mathrm{Ca}_{3}\left(\mathrm{PO}_{4}\right)_{2}$ (Sugiyama et al., 2002).

Also, effective Cr(VI) removal at high concentration (app. 500 ppm) could be achieved using $\mathrm{BaCl}_{2}$ at $\mathrm{pH}$ 9.5-10 to induce precipitation of heavily soluble $\mathrm{BaCrO}_{4}$. The level of $\mathrm{Cr}(\mathrm{VI})$ was decreased to $1.2 \mathrm{ppm}$, and after treatment with $\mathrm{Ca}(\mathrm{OH})_{2}$ to less than $0.1 \mathrm{ppm}$. $\mathrm{BaCrO}_{4}$ is a commercial product with limited application (it is under specific national regulations and thus sporadically used for traffic signalization). This technology justifies economic (marketable product) and from the other side high residual chloride concentration 
represent pollution problem (COD interference). Using this technology could not attain EU and WHO prescribed value of 0.05 ppm (Zelmanov and Semiat, 2011).

\subsubsection{Leaching experiment - Toxicity Characteristic (TCLP)}

Table S13. The metal concentrations $\left(\mathrm{mg} \mathrm{kg}^{-1}\right)$ in the membranes

\begin{tabular}{lllllll}
\hline \multirow{2}{*}{ Membrane } & \multicolumn{5}{c}{ Concentration $\left(\mathrm{mg} \mathrm{kg}^{-1}\right)$} \\
\cline { 2 - 7 } & $\mathrm{Cr}$ & $\mathrm{Cd}$ & $\mathrm{Pb}$ & $\mathrm{Zn}$ & $\mathrm{Cu}$ & $\mathrm{Ni}$ \\
\hline Cell-EL & $<\mathrm{MDL}^{*}$ & 0.20 & $<\mathrm{MDL}^{*}$ & 2.2 & 6.5 & $<\mathrm{MDL}^{*}$ \\
Cell-EL-TA & $<\mathrm{MDL}^{*}$ & 0.18 & $<\mathrm{MDL}^{*}$ & 2.17 & 6.47 & $<\mathrm{MDL}^{*}$ \\
* the amount of metal less than MDL (method detection limit, the limits of detection for metals: chromium 0.025 \\
mg L ${ }^{-1}$ (EPA 218.3), lead 1 mg L ${ }^{-1}$ (EPA 239.1) and nickel 0.025 $\mathrm{mg} \mathrm{L}^{-1}$ (EPA 218.3)
\end{tabular}

The toxicity characteristics using procedure (TCLP) were investigated in order to confirm validity of used membranes in adsorption/desorption cycles. Their characterization as nonhazardous is important as they may pose environmental risks and would otherwise require further stabilization and safe disposal. Hence, the results of TCLP testing are main criteria about membrane manipulation and possible application in environmental protection.

Table S14. The leaching results of the filter cake

\begin{tabular}{|c|c|c|c|c|c|c|c|}
\hline Sample & & $\mathrm{Cr}$ & $\mathrm{Cd}$ & $\mathrm{Pb}$ & $\mathrm{Zn}$ & $\mathrm{Cu}$ & $\mathrm{Ni}$ \\
\hline Cell-EL & & $<\mathrm{MDL}$ & 0.01 & $<\mathrm{MDL}$ & 0.110 & 0.325 & $<\mathrm{MDL}$ \\
\hline Cell-EL-TA & & $<\mathrm{MDL}$ & 0.009 & $<\mathrm{MDL}$ & 0.108 & 0.323 & $<\mathrm{MDL}$ \\
\hline
\end{tabular}

*Concentration limit values, given in $\mathrm{mg} \mathrm{dm}^{-3}$, are from national regulation stipulated by the Republic of Serbia (Official Gazette RS 48/2012 and 1/2016, and Official Gazette RS 88/2010);

The leaching potential of various heavy metal ions from Cell-EL and Cell-EL-TA membranes was below values regulated by national authorities. Concerning the maximum permissible values for the acceptability of obtained membranes, the leaching results indicate that investigated samples verify that there is no hazard posed to the environment when they used. 


\subsubsection{Microbial degradation of cellulose, lignin and tannic acid}

A significant advantage of bio-based materials is their biodegradability. Most of the cellulolytic microorganisms belong to eubacteria and fungi, even there are some anaerobic protozoa and slime molds able to degrade cellulose. The cellulase systems of the mesophilic fungi Trichoderma reesei and Phanerochaete chrysosporium and aerobic cellulolytic bacteria species (genera Cellulomonas, Pseudomonas, and Streptomyces) are the most examined (Pérez et al., 2002). Microbial degradation of lignin may occurr through organisms like fungi (Whiterot fungi), but there are reports of bacteria that can break down lignin. Lignin-degrading bacteria can be divided into 3 classes: Actinomycetes, $\alpha$-Proteobacteria and $\gamma$-Proteobacteria (Bugg et al., 2011; Janusz et al., 2017). This group of microbes widely distributed in terrestrial and aquatic habitats, product the secondary metabolites and uses the extracellular enzymes, hence they are considered major decomposers of lignocelluloses in soils. Certain fungal strains (Penicillium commune, Aspergillus niger, Aspergillus rugulosa, Aspergillus terricola, Aspergillus ornatus and Aspergillus fumigatus) (Cruz-Hernández et al., 2005) and bacteria can degrade tannins. Bacterial species with ability to degrade these polyphenolics are Citrobacter, Streptococcus and Corynebacterium (Ilori et al., 2007). These data encourage researchers to further develop biodegradable membranes whose constituents are cellulose, lignin and tannin, as well as to investigate their biodegradation. Researchers will deal with this issue in their further work.

\subsection{Consideration of adsorption mechanism supported by the semi-empirical calculation}

From Fig. 8a. and 8b. it could be observed that after formation of coordination complex with $\mathrm{Pb}^{2+}$ and $\mathrm{Ni}^{2+}$ ions, adsorption in spectra shows slight displacements, while complex with $\mathrm{Cr}(\mathrm{VI})$ in spectra causes a small change in skeletal structure of cellulosic material. Intensity of peaks in region characteristic for hydroxyl groups showed small change (Fig. 8a and Fig. 8b). Also, the formation of complex with metal ions leads to decreased the intensity of peaks in region 2962-2873 $\mathrm{cm}^{-1}$ for all complex's Cell-EL-TA and Cell-EL/Pb ${ }^{2+}$, while value of the peaks for complex's Cell-EL/Ni ${ }^{2+}$ and $\mathrm{Cr}(\mathrm{VI})$ are decreased and shifted to $2920-2846 \mathrm{~cm}^{-1}$. Compared the FT-IR spectra of adsorbents before and after adsorption a small change was observed in all spectra for band at $1595 \mathrm{~cm}^{-1}$. The changes are followed by higher decrease absorption band, indicating on the interaction between of amino functional group in adsorbents and cation/oxyanion. Additionally, the interaction of metal ion with hydroxyl/oxy group in 
Cell-EL and Cell-EL-TA adsorbents cause the appearance of a new peaks at $1054 \mathrm{~cm}^{-1}$ (Fig. $8 \mathrm{a})$ and $1058 \mathrm{~cm}^{-1}$ (Fig. 8b). This band is attributed to symmetric stretching vibration of C-O group. The wavelengths changes in region $1380-1314 \mathrm{~cm}^{-1}$ is a result of complexation of $\mathrm{Cr}(\mathrm{VI})$ by forming specific/non-specific interactions with hydrogen from amino/hydroxyl functional group of adsorbents.
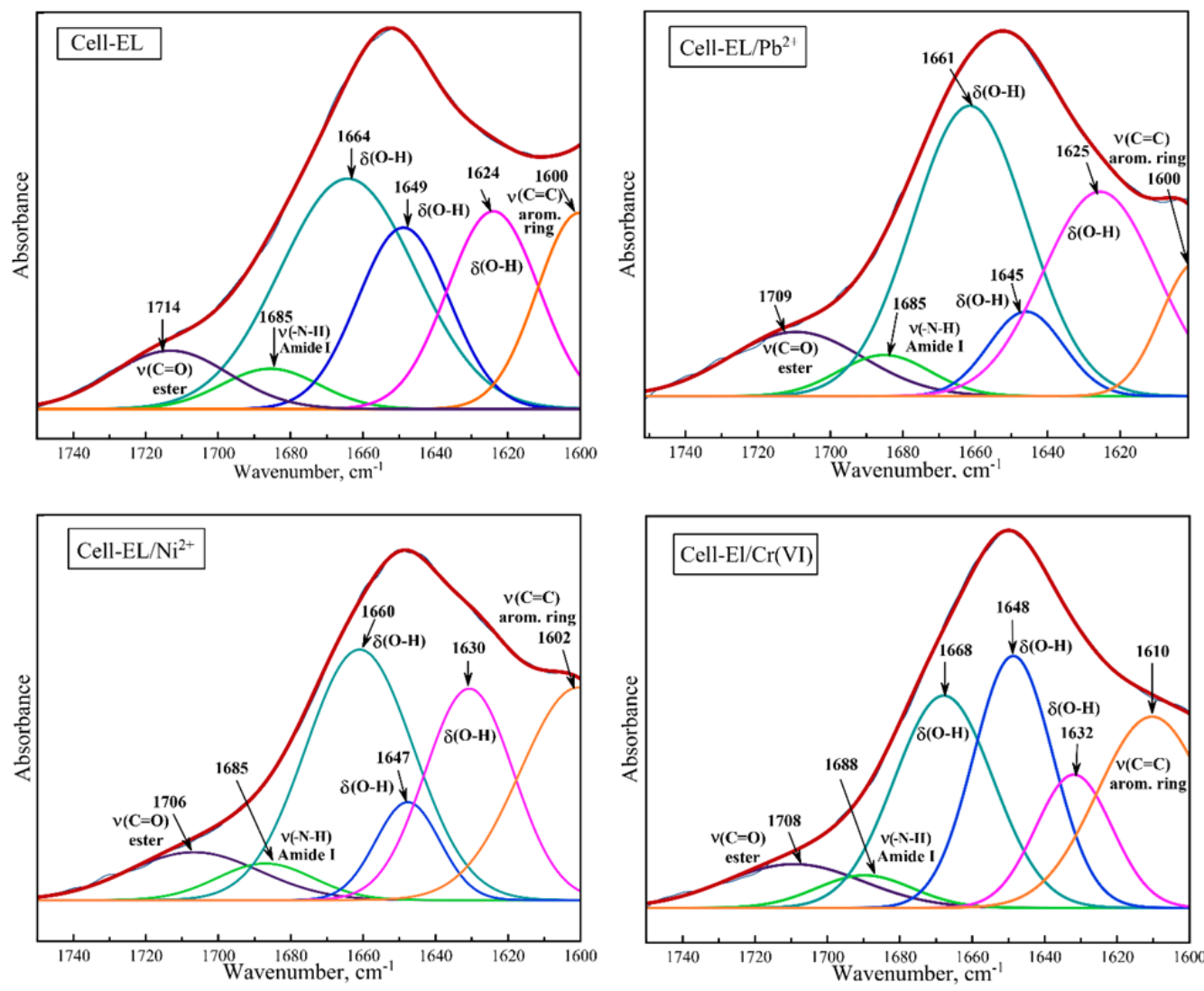

Fig. S5. Deconvolution of spectra before and after adsorption in region $1750-1600 \mathrm{~cm}^{-1}$ 

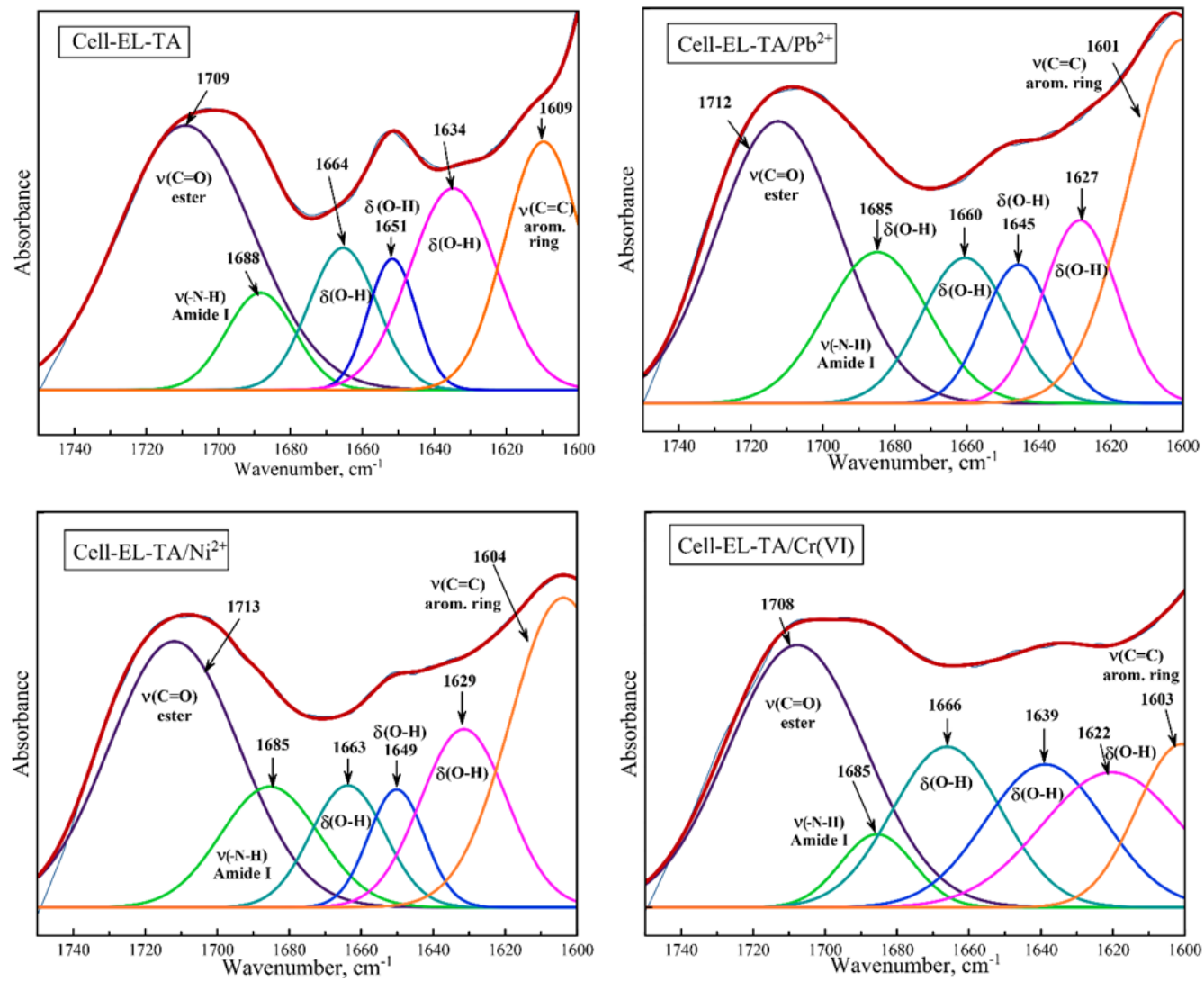

Fig S6. Deconvolution of spectra before and after adsorption in region $1750-1600 \mathrm{~cm}^{-1}$

Table S15. The binding enthalpy for the complexes

\begin{tabular}{cccc}
\hline Complex & $\Delta H_{\mathrm{b}}, \mathrm{kJ} / \mathrm{mol}$ & Complex & $\Delta H_{\mathrm{b}}, \mathrm{kJ} / \mathrm{mol}$ \\
\hline Lignin $-\mathrm{Pb}^{2+}$ & -42.2 & $\mathrm{TA}-\mathrm{Pb}^{2+}$ & -32.0 \\
Lignin $-\mathrm{Pb}^{2+}$ & -27.2 & $\mathrm{TA}-\mathrm{Pb}^{2+}$ & -23.2 \\
Lignin $-\mathrm{Pb}^{2+}$ & -24.1 & $\mathrm{TA}-\mathrm{Pb}^{2+}$ & 36.6 \\
Lignin $-\mathrm{Pb}^{2+}$ & -7.3 & $\mathrm{TA}-\mathrm{Ni}^{2+}$ & 1.6 \\
Lignin $-\mathrm{Ni}^{2+}$ & -65.3 & $\mathrm{TA}-\mathrm{Ni}^{2+}$ & 18.6 \\
Lignin $-\mathrm{Ni}^{2+}$ & -46.4 & $\mathrm{TA}-\mathrm{Ni}^{2+}$ & 91.2 \\
Lignin $-\mathrm{HCrO}_{4}{ }^{-}$ & -52.6 & $\mathrm{TA}-\mathrm{HCrO}_{4}^{-}$ & -55.0 \\
Lignin $-\mathrm{HCrO}_{4}{ }^{-}$ & -38.9 & $\mathrm{TA}-\mathrm{HCrO}_{4}^{-}$ & -49.5 \\
Lignin $-\mathrm{HCrO}_{4}{ }^{-}$ & -21.1 & $\mathrm{TA}-\mathrm{HCrO}_{4}^{-}$ & -45.4 \\
Lignin $-\mathrm{HCrO}_{4}{ }^{-}$ & -9.8 & - & - \\
\hline
\end{tabular}




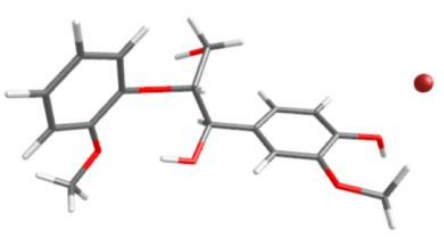

a)
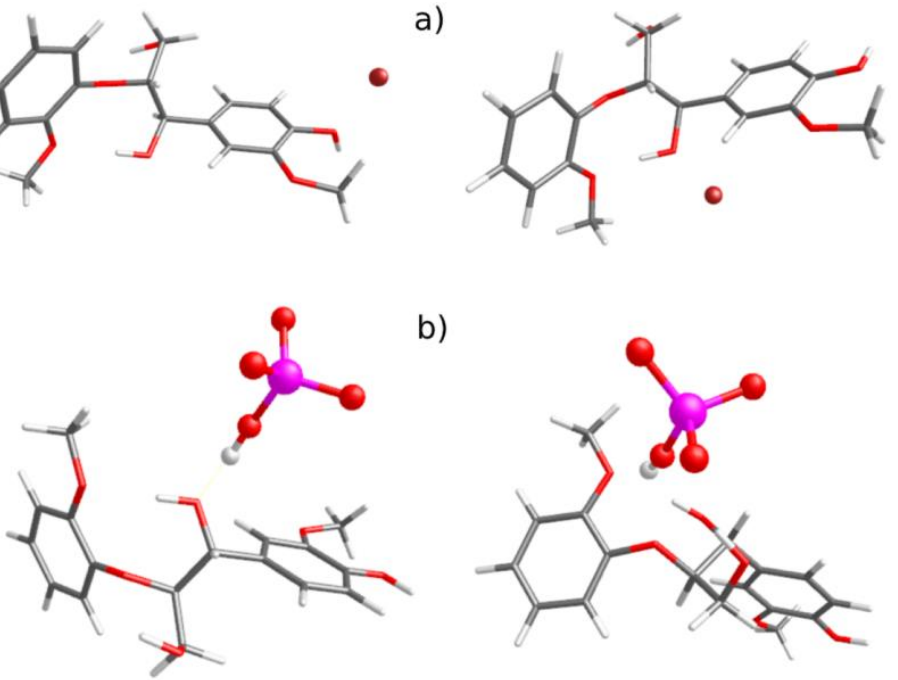

b)

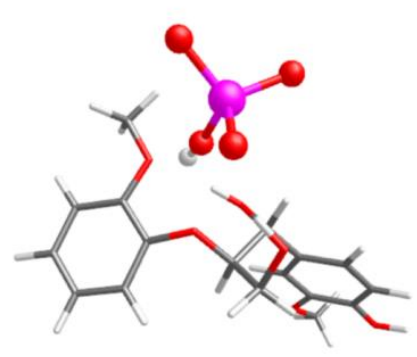

Fig S7. Structures of lignin model compound in complex with a) $\mathrm{Pb}^{2+}$, and b) $\mathrm{HCrO}_{4}{ }^{-}$ion.
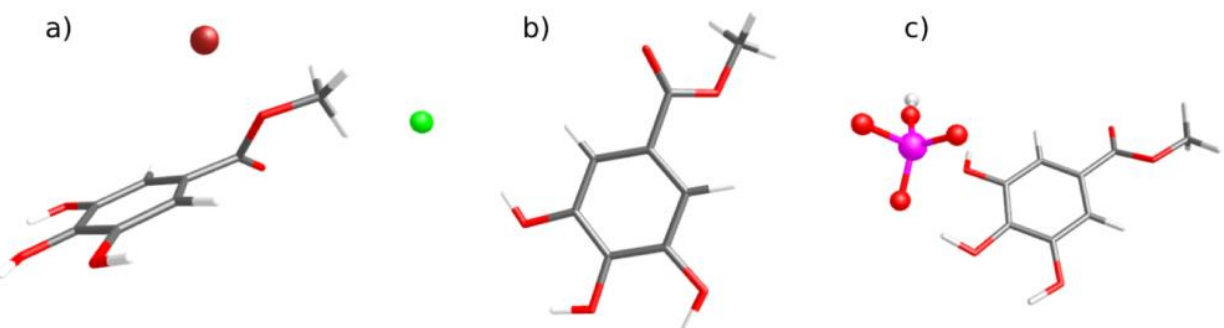

Fig S8. Structures of tannic acid model compound in complex with a) $\mathrm{Pb}^{2+}$, b) $\mathrm{Ni}^{2+}$, and c) $\mathrm{HCrO}_{4}^{-}$ion.

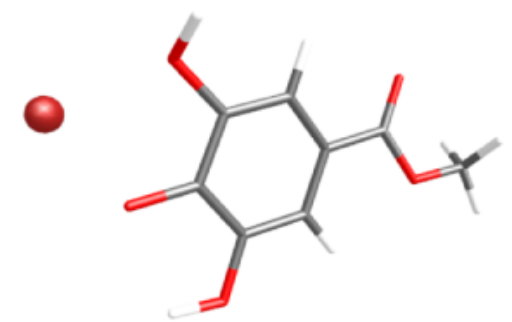

Fig. S9. Structures of tannate model compound ( $p-\mathrm{OH}$ ionized) complex with $\mathrm{Pb}^{2+}$.

\subsection{Bed column study}

Breakthrough curve modeling is very important for describing and analyzing the labscale column studies for the purpose of industrial applications. In this study, Bohart-Adams, Yoon-Nelson and Clark models were applied for predicting the dynamic behavior of the column. The Adams-Bohart model assumes that the adsorption rate is proportional to both the 
residual capacity of the adsorbent and the concentration of the adsorbing species (Biswas and Mishra, 2015). Linear form of Adams- Bohart model is given by the equation below: Eq. S27:

$\ln \left(\frac{C_{t}}{C_{0}}\right)=K_{A B} C_{0} t-\frac{K_{A B} N_{0} Z}{U_{0}}$

Where, $\mathrm{C}_{0}\left(\mathrm{~mol} \mathrm{dm}{ }^{-3}\right)$ is initial concentration, $\mathrm{C}_{\mathrm{t}}\left(\mathrm{mol} \mathrm{dm}^{-3}\right)$ is concentration of effluent at time $\mathrm{t}, \mathrm{Z}(\mathrm{cm})$ is bed depth of column, $\mathrm{N}_{0}\left(\mathrm{mg} \mathrm{dm}^{-3}\right)$ is maximum dye uptake capacity per unit volume of adsorbent column, $\mathrm{U}_{0}\left(\mathrm{~cm} \mathrm{~min}^{-1}\right)$ is linear velocity of influent dye solution, $\mathrm{K}_{\mathrm{AB}}\left(\mathrm{dm}^{3}\right.$ $\mathrm{mg}^{-1} \mathrm{~min}^{-1}$ ) is the kinetic constant.

The Yoon-Nelson model assumed that the rate of decrease in the probability of adsorption for each adsorbate molecule is proportional to the probability of adsorbate adsorption and the probability of an adsorbate's breakthrough point. (Biswas and Mishra, 2015). The Yoon-Nelson equation in linearized form is expressed as Eq. S28:

$\ln \left(\frac{C_{t}}{C_{0}-C_{t}}\right)=K_{Y N} \Theta-K_{Y N} t$

where $C_{0}\left(\mathrm{~mol} \mathrm{dm}{ }^{-3}\right)$ is initial concentration of heavy metal, $\mathrm{C}_{\mathrm{t}}\left(\mathrm{mol} \mathrm{dm} \mathrm{dm}^{-3}\right)$ is concentration of heavy metal at time $t, t(\mathrm{~min})$ is flow time, $\Theta(\mathrm{min})$ is time required for $50 \%$ breakthrough, $K_{\mathrm{YN}}\left(\min ^{-1}\right)$ is the Yoon-Nelson rate constant.

Clark model (Lee et al., 2015), is given by Eqs. S29-S32. Clark model was based on the use of a mass-transfer concept in combination with the Freundlich isotherm constant.

$\frac{C}{C_{0}}=\left(\frac{1}{1+A e^{-r t}}\right)^{\frac{1}{n}-1}$

$A=\left(\frac{C_{0}{ }^{n-1}}{C_{b}{ }^{n-1}}-1\right) e^{r t_{b}}$

$r=\frac{k_{T}}{U_{0}} v(n-1)$

Where $n$ is the Freundlich constant, $C \mathrm{~b}$ is the concentration at breakthrough $\left(\mathrm{mmol} \cdot \mathrm{L}^{-1}\right), k_{\mathrm{T}}$ is the mass-transfer rate coefficient $\left(\mathrm{min}^{-1}\right)$ and $v$ is the migration velocity of the concentration fronts in the bed $\left(\mathrm{cm} \cdot \mathrm{min}^{-1}\right)$, determined by the following equation Eq. S32:

$v=\frac{U_{0} C_{0}}{N_{0}+C_{0}}$ 

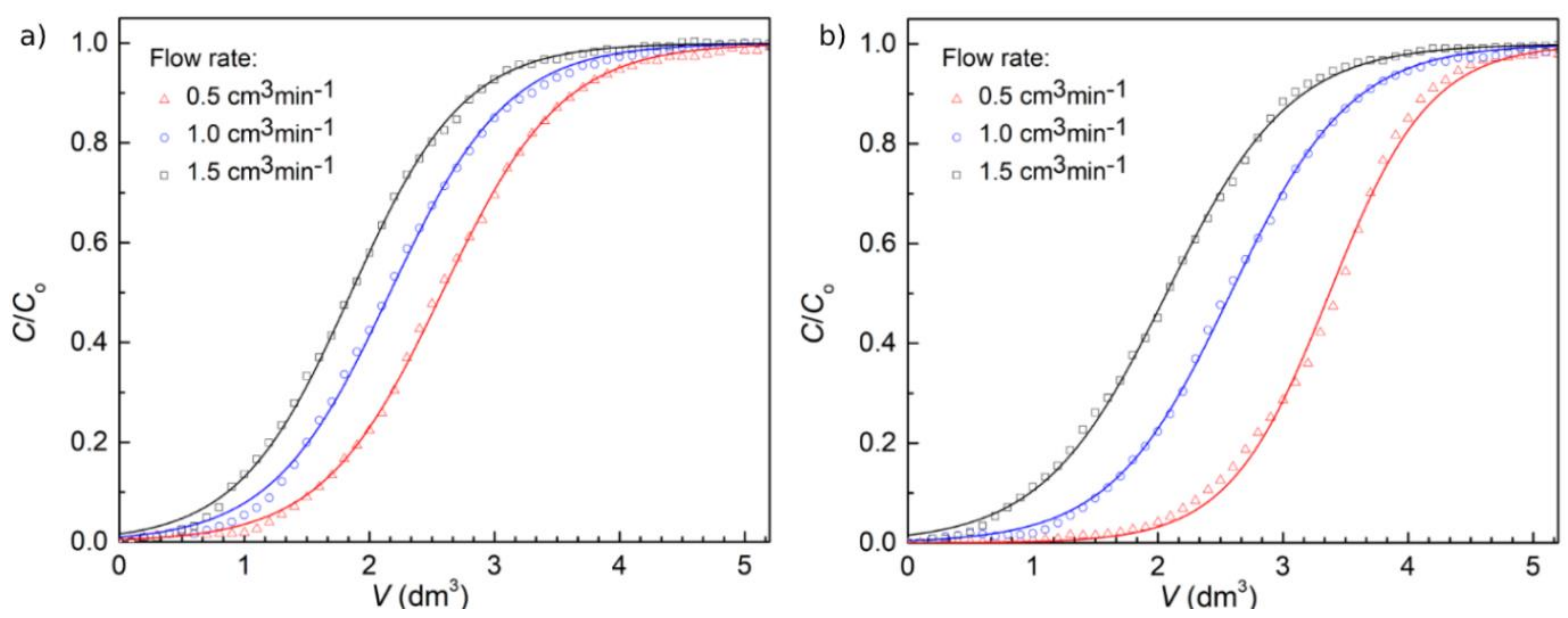

Fig. S10. The Bohart-Adams fitted breakthrough curves of $\mathrm{Ni}^{2+}$ adsorption $\left(C_{\mathrm{i}}\left[\mathrm{Ni}^{2+}\right]=10.5 \mathrm{mg}\right.$ $\mathrm{dm}^{-3}$ ) by a) Cell-EL mads $($ Cell-EL $)=487.5 \mathrm{mg} ; \mathrm{pH}$ 6) and b) Cell-EL-TA ( $m_{\text {ads }}($ Cell-EL$\mathrm{TA})=502.5 \mathrm{mg} ; \mathrm{pH}=7)$, at different flow rate $\left(\mathrm{BV}=0.75 \mathrm{~cm}^{3}\right)$
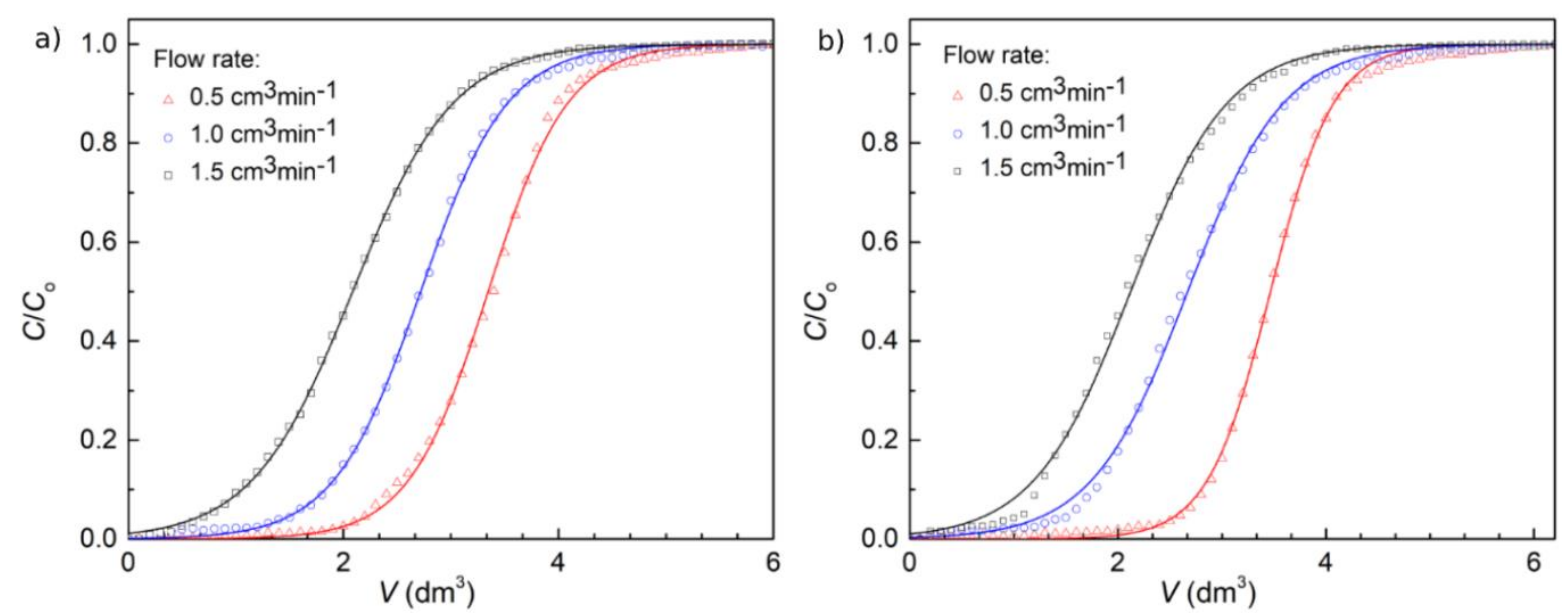

Fig. S11. The Bohart-Adams fitted breakthrough curves of $\mathrm{Pb}^{2+}$ adsorption $\left(C_{\mathrm{i}}\left[\mathrm{Pb}^{2+}\right]=11.0 \mathrm{mg}\right.$ $\mathrm{dm}^{-3}$ ) by a) Cell-EL $m_{\text {ads }}($ Cell-EL $)=487.5 \mathrm{mg} ; \mathrm{pH}$ 6) and b) Cell-EL-TA $m_{\mathrm{ads}}($ Cell-EL$\mathrm{TA})=502.5 \mathrm{mg} ; \mathrm{pH}=7$, at different flow rate $\left(\mathrm{BV}=0.75 \mathrm{~cm}^{3}\right)$ 

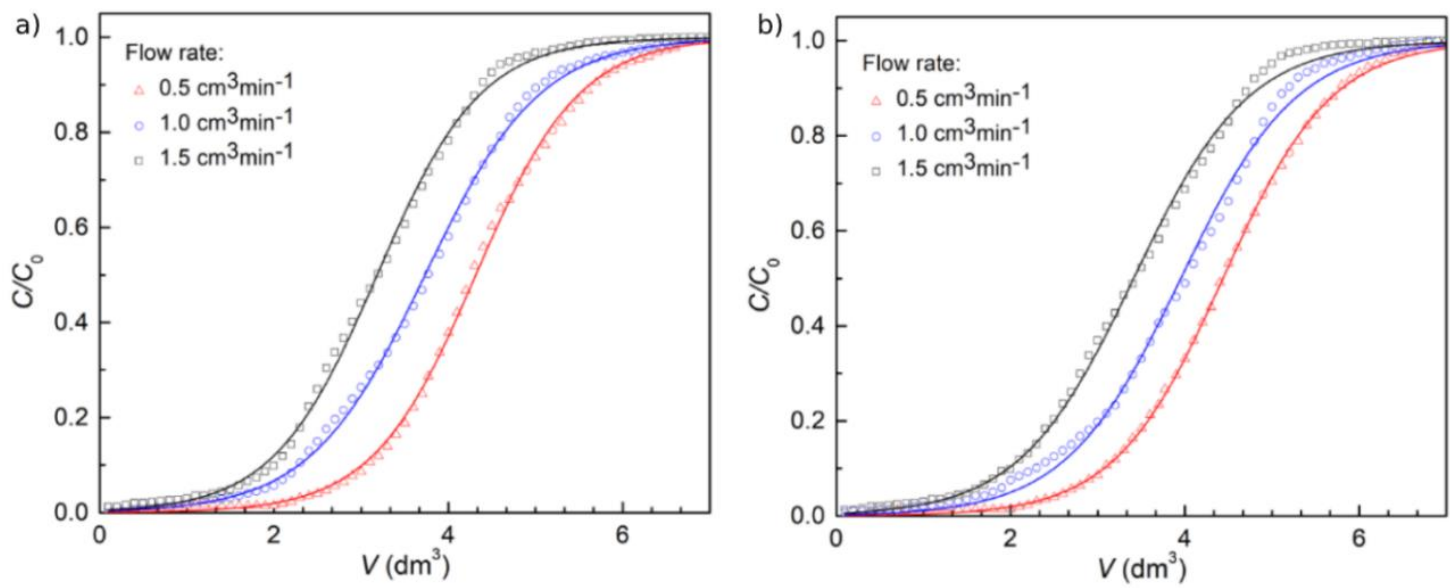

Fig. S12. The Bohart-Adams fitted breakthrough curves of $\mathrm{Cr}(\mathrm{VI})$ adsorption $\left(C_{\mathrm{i}}[\mathrm{Cr}(\mathrm{VI}]\right.$ $\left.=12.0 \mathrm{mg} \mathrm{dm}^{-3}\right)$ by a) Cell-EL $\left(\mathrm{m}_{\mathrm{ads}}(\right.$ Cell-EL $\left.)=487.5 \mathrm{mg} ; \mathrm{pH} 6\right)$ and b) Cell-EL-TA $\left(m_{\mathrm{ads}}\right.$ $($ Cell-EL-TA $)=502.5 \mathrm{mg} ; \mathrm{pH}=7)$ at different flow rate $\left(\mathrm{BV}=0.75 \mathrm{~cm}^{3}\right)$ 
3.7 Comparison of the adsorption performance of Cell-EL and Cell-EL-TA with literature data, and assessment of their performance for mining wastewater treatment

Table S16. Overview of adsorption capacities and kinetic data of modified cellulose, epoxy lignin and tannic acid based adsorbents

\begin{tabular}{|c|c|c|c|c|c|c|c|}
\hline Ref. & Adsorbent & $\begin{array}{c}C_{\mathrm{i}} \\
\left(\mathrm{mg} \mathrm{dm}^{-3}\right)\end{array}$ & $\begin{array}{c}\mathrm{T} \\
\left({ }^{0} \mathrm{C}\right)\end{array}$ & $\mathrm{Pb}^{2+}$ & $\mathrm{Ni}^{2+}$ & $\mathrm{Cr}(\mathrm{VI})$ & $\begin{array}{l}\text { Adsorption isotherms; } \\
\text { kinetics }\end{array}$ \\
\hline $\begin{array}{l}\text { (Zhang and } \\
\text { Wang, 2015) }\end{array}$ & $\begin{array}{l}\text { Lignocellulose/montmorillonite } \\
\text { (LNC/MMT) nanocomposite }\end{array}$ & $0.0032 *$ & 70 & & 94.86 & & $\begin{array}{l}\text { Langmuir; pseudo-second-order, } \\
k_{2}=4.2 \times 10^{-3} \mathrm{~g} \mathrm{mg}^{-1} \mathrm{~min}^{-1}\end{array}$ \\
\hline $\begin{array}{l}\text { (Shen et al., } \\
2009 \text { ) }\end{array}$ & $\begin{array}{l}\text { Diethylenetriamine-bacterial cellulose } \\
\text { (EABC) }\end{array}$ & 100 & 25 & 31.41 & & & $\begin{array}{l}\text { Langmuir; pseudo-second-order, } \\
k_{2}=1.0 \times 10^{-3} \mathrm{~g} \mathrm{mg}^{-1} \mathrm{~min}^{-1}\end{array}$ \\
\hline $\begin{array}{l}(\mathrm{Xu} \text { et al., } \\
2017)\end{array}$ & $\begin{array}{l}\text { Black wattle tannin-immobilized } \\
\text { nanocellulose }\end{array}$ & 50 & r.t. & 53.371 & & 104.592 & $\begin{array}{l}\text { Sips; pseudo-second-order, } k_{2}= \\
\left.4.5 \times 10^{-2} \mathrm{~g} \mathrm{mg}^{-1} \mathrm{~min}^{-1} \text { (for } \mathrm{Pb}{ }^{2+}\right), k_{2}= \\
6.77 \times 10^{-2} \mathrm{~g} \mathrm{mg}^{-1} \mathrm{~min}^{-1} \text { (for } \mathrm{Cr}(\mathrm{VI})\end{array}$ \\
\hline $\begin{array}{l}\text { (Liu et al., } \\
2013)\end{array}$ & Aminated epoxy-lignin & 300 & 30 & 55.3 & & & $\begin{array}{l}\text { Langmuir; pseudo-second-order, } \\
k_{2}=2.95 \times 10^{-3} \mathrm{~g} \mathrm{mg}^{-1} \mathrm{~min}^{-1}\end{array}$ \\
\hline $\begin{array}{l}\text { (Maremeni et } \\
\text { al., 2018) }\end{array}$ & $\begin{array}{l}\text { Diphenylcarbazide-Grafted Macadamia } \\
\text { Nutshell Powder }\end{array}$ & 150 & - & & & 72.12 & $\begin{array}{l}\text { Langmuir; pseudo-second-order, } \\
k_{2}=8.63 \times 10^{-3} \mathrm{~g} \mathrm{mg}^{-1} \mathrm{~min}^{-1}\end{array}$ \\
\hline $\begin{array}{l}\text { (Albadarin et } \\
\text { al., 2017) }\end{array}$ & Modified masau stone (CMMS) & 100 & 20 & & & 87.32 & Langmuir; pseudo-second-order, \\
\hline $\begin{array}{l}\text { (Oo et al., } \\
2009)\end{array}$ & $\begin{array}{l}\text { Rhizophora apiculata mangrove } \\
\text { polyflavonoid tannins }\end{array}$ & 10 & $\mathrm{rt}$ & 31.32 & & & $\begin{array}{l}\text { Langmuir; pseudo-second-order } \\
k_{2}=1.5481 \times 10^{-3} \mathrm{~g} \mathrm{mg}^{-1} \mathrm{~min}^{-1}\end{array}$ \\
\hline $\begin{array}{l}\text { (Zhou et al., } \\
\text { 2011) }\end{array}$ & Cell- $g$-GMA- $\beta$-CDN ${ }^{+}$ & 50 & 18 & & & 61.05 & $\begin{array}{l}\text { Langmuir; pseudo- second -order } \\
k_{2}=8.50 \times 10^{-1} \mathrm{~g} \mathrm{mg}^{-1} \mathrm{~min}^{-1}\end{array}$ \\
\hline
\end{tabular}

$* \mathrm{~mol} / \mathrm{L} ; * \mathrm{mmol} / \mathrm{L}$ 
Polluted industrial mine waters often contain more heavy metals and some anions of different concentrations. As a consequence of such a complex environment, where there is a very high competition between ions, it is a great challenge to develop an adsorbent effective at the same time for the removal of cations and anions. In order to evaluate the performance of Cell-EL and Cell-EL-TA adsorbents, tests were performed with the samples of real effluent (wastewater from the Serbian mining industry). The obtained results are presented in Table S17.

Table S17. The removal of oxyanion/cation by Cell-EL and Cell-EL-TA from real wastewater sample ( $\mathrm{pH}$ adjusted to $\sim 6.5)$

\begin{tabular}{|c|c|c|c|c|c|}
\hline \multirow{3}{*}{$\begin{array}{l}\text { Wastewater } \\
\text { anions/cations }\end{array}$} & \multirow{3}{*}{$\begin{array}{c}\text { before } \\
\text { treatment } \\
\mathrm{C}_{\mathrm{i}}\left(\mathrm{mg} \mathrm{dm}^{-3}\right) \\
\end{array}$} & \multirow{2}{*}{\multicolumn{2}{|c|}{$\begin{array}{l}\text { after treatment } \\
\mathrm{C}_{\mathrm{f}}\left(\mathrm{mg} \mathrm{dm}^{-3}\right)\end{array}$}} & \multirow{2}{*}{\multicolumn{2}{|c|}{ Removal (\%) }} \\
\hline & & & & & \\
\hline & & Cell-EL & Cell-EL-TA & Cell-EL & Cell-EL-TA \\
\hline $\mathrm{Cu}^{2+}$ & 149.5 & 103.6 & 107.5 & 28.1 & 30.7 \\
\hline $\mathrm{Ca}^{2+}$ & 443.3 & 298.3 & 304.6 & 31.3 & 32.7 \\
\hline $\mathrm{Cd}^{2+}$ & 3.2 & 2.1 & 2.2 & 31.2 & 34.4 \\
\hline $\mathrm{Mg}^{2+}$ & 127.4 & 111.8 & 115.8 & 9.1 & 12.2 \\
\hline $\mathrm{Mn}^{2+}$ & 8.4 & 6.8 & 6.9 & 17.6 & 19.0 \\
\hline $\mathrm{Ni}^{2+}$ & 31.8 & 17.5 & 19.7 & 38.1 & 44.9 \\
\hline $\mathrm{Pb}^{2+}$ & 2.9 & 1.4 & 1.5 & 48.3 & 51.7 \\
\hline $\mathrm{Zn}^{2+}$ & 17.7 & 13.4 & 14.1 & 20.3 & 24.3 \\
\hline $\mathrm{Cr}(\mathrm{VI})$ & 0.05 & I & 1 & 100.00 & 100.0 \\
\hline $\mathrm{As}(\mathrm{V})$ & 9.6 & 6.1 & 6.1 & 36.4 & 36.4 \\
\hline $\mathrm{Cl}^{-}$ & 67.4 & 65.3 & 66.0 & 2.1 & 3.1 \\
\hline $\mathrm{SO}_{4}^{2-}$ & 2398.7 & 2124.1 & 2127.7 & 11.3 & 11.4 \\
\hline
\end{tabular}

The obtained results, presented in Table S17, showed the potential of Cell-EL and Cell-EL-TA adsorbents for the purification of real effluents. Obviously, there is competition among all ions present. Industrial wastewater often contains large amounts of light metals that greatly interfere with the adsorption of the target heavy metal. Therefore, the adsorption process depends not only on the surface properties of adsorbent, physico-chemical characteristics of the solution such as temperature and $\mathrm{pH}$, but also on the amount of other ions and their concentrations. In addition to the above, the size of the ionic and ionic hydrated radii should be taken into account, as well as electronegativity, which have a great influence on the competition between metal ions and lead to a reduced percentage of targeted metals removal. 


\section{References}

Ain Zainuddin, N., Azwan Raja Mamat, T., Imam Maarof, H., Wahidah Puasa, S., Rohana Mohd Yatim, S., 2019. Removal of Nickel, Zinc and Copper from Plating Process Industrial Raw Effluent Via Hydroxide Precipitation Versus Sulphide Precipitation. IOP Conf. Ser. Mater. Sci. Eng. 551. https://doi.org/10.1088/1757-899X/551/1/012122

Albadarin, A.B., Solomon, S., Kurniawan, T.A., Mangwandi, C., Walker, G., 2017. Single, simultaneous and consecutive biosorption of $\mathrm{Cr}(\mathrm{VI})$ and Orange II onto chemically modified masau stones. J. Environ. Manage. 204, 365-374. https://doi.org/10.1016/j.jenvman.2017.08.042

Aniceto, J.P.S., Cardoso, S.P., Silva, C.M., 2016. General optimization strategy of simulated moving bed units through design of experiments and response surface methodologies. Comput. Chem. Eng. 90, 161-170. https://doi.org/10.1016/j.compchemeng.2016.04.028

Banerjee, M., Bar, N., Basu, R.K., Das, S.K., 2018. Removal of Cr(VI) from Its Aqueous Solution Using Green Adsorbent Pistachio Shell: a Fixed Bed Column Study and GAANN Modeling. Water Conserv. Sci. Eng. 3, 19-31. https://doi.org/10.1007/s41101-0170039-x

Bestgen, J.O., Cetin, B., Tanyu, B.F., 2016. Effects of extraction methods and factors on leaching of metals from recycled concrete aggregates. Environ. Sci. Pollut. Res. 23, 12983-13002. https://doi.org/10.1007/s11356-016-6456-0

Biswas, S., Mishra, U., 2015. Continuous Fixed-Bed Column Study and Adsorption Modeling: Removal of Lead Ion from Aqueous Solution by Charcoal Originated from Chemical Carbonization of Rubber Wood Sawdust. J. Chem. 2015. https://doi.org/10.1155/2015/907379

Bugg, T.D.H., Ahmad, M., Hardiman, E.M., Rahmanpour, R., 2011. Pathways for degradation of lignin in bacteria and fungi. Nat. Prod. Rep. 28, 1883-1896. https://doi.org/10.1039/c1np00042j

Bykov, I., 2008. Characterization of Natural and Technical Lignins using FTIR Spectroscopy. Construction 43.

Chung, C., Lee, M., Choe, E.K., 2004. Characterization of cotton fabric scouring by FT-IR ATR spectroscopy. Carbohydr. Polym. 58, 417-420. https://doi.org/10.1016/j.carbpol.2004.08.005

Cruz-Hernández, M., Contreras-Esquivel, J.C., Lara, F., Rodríguez, R., Aguilar, C.N., 2005. 
Isolation and evaluation of tannin-degrading fungal strains from the Mexican desert. Zeitschrift fur Naturforsch. - Sect. C J. Biosci. 60, 844-848. https://doi.org/10.1515/znc2005-11-1205

Demirbas, A., 2004. Adsorption of lead and cadmium ions in aqueous solutions onto modified lignin from alkali glycerol delignication. J. Hazard. Mater. 109, 221-226. https://doi.org/10.1016/j.jhazmat.2004.04.002

Demirbaş, A., 2005. Adsorption of $\mathrm{Cr}$ (III) and $\mathrm{Cr}(\mathrm{VI})$ ions from aqueous solutions on to modified lignin. Energy Sources 27, 1449-1455. https://doi.org/10.1080/009083190523352

Dünwald, H., Wagner, C., 1934. Methodik der Messung von Diffusiongeschwindigkeiten bei Losungsvorgangen von Gasen in festen Phasen (Measurement of Diffusion Rate in the Process of Dissolving Gases in Solid Phases). Zeitschrift für Phys. Chemie B24, 53-58.

Esteves, B., Marques, A.V., Domingos, I., Pereira, H., 2013. Chemical changes of heat treated pine and eucalypt wood monitored by ftir. Maderas Cienc. y Tecnol. 15, 245-258. https://doi.org/10.4067/S0718-221X2013005000020

Foo, K.Y., Hameed, B.H., 2010. Insights into the modeling of adsorption isotherm systems. Chem. Eng. J. 156, 2-10. https://doi.org/10.1016/j.cej.2009.09.013

Fu, F., Wang, Q., 2011. Removal of heavy metal ions from wastewaters: A review. J. Environ. Manage. 92, 407-418. https://doi.org/10.1016/j.jenvman.2010.11.011

Gosselink, R.J.A., Abächerli, A., Semke, H., Malherbe, R., Käuper, P., Nadif, A., Van Dam, J.E.G., 2004. Analytical protocols for characterisation of sulphur-free lignin. Ind. Crops Prod. 19, 271-281. https://doi.org/10.1016/j.indcrop.2003.10.008

Guo, X., Zhang, S., Shan, X. quan, 2008. Adsorption of metal ions on lignin. J. Hazard. Mater. 151, 134-142. https://doi.org/10.1016/j.jhazmat.2007.05.065

Guo, Z.R., Zhang, G., Fang, J., Dou, X., 2006. Enhanced chromium recovery from tanning wastewater. J. Clean. Prod. 14, 75-79. https://doi.org/10.1016/j.jclepro.2005.01.005

Ilori, M.O., Adebusoye, S.A., Amund, O.O., Oyetoran, B.O., 2007. A study of tannic acid degradation by soil bacteria. Pakistan J. Biol. Sci. 10, 3224-3227. https://doi.org/10.3923/pjbs.2007.3224.3227

Jablonskis, A., Arshanitsa, A., Arnautov, A., Telysheva, G., Evtuguin, D., 2018. Evaluation of Ligno Boost ${ }^{\mathrm{TM}}$ softwood kraft lignin epoxidation as an approach for its application in cured epoxy resins. Ind. Crops Prod. 112, 225-235. https://doi.org/10.1016/j.indcrop.2017.12.003

Janusz, G., Pawlik, A., Sulej, J., Świderska-Burek, U., Jarosz-Wilkolazka, A., Paszczyński, A., 
2017. Lignin degradation: Microorganisms, enzymes involved, genomes analysis and evolution. FEMS Microbiol. Rev. 41, 941-962. https://doi.org/10.1093/femsre/fux049

Karanac, M., Đolić, M., Veljović, Đ., Rajaković-Ognjanović, V., Veličković, Z., Pavićević, V., Marinković, A., 2018. The removal of $\mathrm{Zn} 2+, \mathrm{Pb} 2+$, and $\mathrm{As}(\mathrm{V})$ ions by lime activated fly ash and valorization of the exhausted adsorbent. Waste Manag. 78, 366-378. https://doi.org/10.1016/j.wasman.2018.05.052

Kavak, D., 2013. Removal of lead from aqueous solutions by precipitation: Statistical analysis and modeling. Desalin. Water Treat. 51, 1720-1726. https://doi.org/10.1080/19443994.2012.714652

Koromilas, N.D., Anastasopoulos, C., Oikonomou, E.K., Kallitsis, J.K., 2019. Preparation of porous polymeric membranes based on a pyridine containing aromatic polyether sulfone. Polymers (Basel). 11, 1-20. https://doi.org/10.3390/polym11010059

Lee, C.G., Kim, J.H., Kang, J.K., Kim, S.B., Park, S.J., Lee, S.H., Choi, J.W., 2015. Comparative analysis of fixed-bed sorption models using phosphate breakthrough curves in slag filter media. Desalin. Water Treat. 55, 1795-1805. https://doi.org/10.1080/19443994.2014.930698

Liu, S., Zeng, J., Tao, D., Zhang, L., 2010. Microfiltration performance of regenerated cellulose membrane prepared at low temperature for wastewater treatment. Cellulose 17, 11591169. https://doi.org/10.1007/s10570-010-9450-6

Liu, X., Zhu, H., Qin, C., Zhou, J., Zhao, J.R., Wang, S., 2013. Adsorption of heavy metal ion from aqueous single metal solution by aminated epoxy-lignin. BioResources 8, 22572269. https://doi.org/10.15376/biores.8.2.2257-2269

Lombardo, S., Thielemans, W., 2019. Thermodynamics of adsorption on nanocellulose surfaces, Cellulose. Springer Netherlands. https://doi.org/10.1007/s10570-018-02239-2

Mahedi, M., Cetin, B., Dayioglu, A.Y., 2019. Leaching behavior of aluminum, copper, iron and zinc from cement activated fly ash and slag stabilized soils. Waste Manag. 95, 334355. https://doi.org/10.1016/j.wasman.2019.06.018

Maremeni, L.C., Modise, S.J., Mtunzi, F.M., Klink, M.J., Pakade, V.E., 2018. Adsorptive Removal of Hexavalent Chromium by Diphenylcarbazide-Grafted Macadamia Nutshell Powder 2018.

Milonjić, S.K., Ruvarac, A.L., Šušić, M. V., 1975. The heat of immersion of natural magnetite in aqueous solutions. Thermochim. Acta 11, 261-266. https://doi.org/10.1016/00406031(75)85095-7

Moussout, H., Ahlafi, H., Aazza, M., Maghat, H., 2018. Critical of linear and nonlinear 
equations of pseudo-first order and pseudo-second order kinetic models. Karbala Int. J. Mod. Sci. 4, 244-254. https://doi.org/10.1016/j.kijoms.2018.04.001

Musyoka, S.M., Ngila, J.C., Moodley, B., Petrik, L., Kindness, A., 2011. Synthesis, characterization, and adsorption kinetic studies of ethylenediamine modified cellulose for removal of $\mathrm{Cd}$ and pb. Anal. Lett. 44, 1925-1936. https://doi.org/10.1080/00032719.2010.539736

Oo, C.W., Kassim, M.J., Pizzi, A., 2009. Characterization and performance of Rhizophora apiculata mangrove polyflavonoid tannins in the adsorption of copper (II) and lead (II). Ind. Crops Prod. 30, 152-161. https://doi.org/10.1016/j.indcrop.2009.03.002

Özverdi, A., Erdem, M., 2006. Cu2+, Cd2+ and Pb2+ adsorption from aqueous solutions by pyrite and synthetic iron sulphide. J. Hazard. Mater. 137, 626-632. https://doi.org/10.1016/j.jhazmat.2006.02.051

Pei, Y., Xu, G., Wu, X., Tang, K., Wang, G., 2019. Removing Pb(II) ions from aqueous solution by a promising absorbent of tannin-immobilized cellulose microspheres. Polymers (Basel). 11. https://doi.org/10.3390/polym11030548

Pérez, J., Muñoz-Dorado, J., De La Rubia, T., Martínez, J., 2002. Biodegradation and biological treatments of cellulose, hemicellulose and lignin: An overview. Int. Microbiol. 5, 53-63. https://doi.org/10.1007/s10123-002-0062-3

Popescu, M.C., Popescu, C.M., Lisa, G., Sakata, Y., 2011. Evaluation of morphological and chemical aspects of different wood species by spectroscopy and thermal methods. J. Mol. Struct. 988, 65-72. https://doi.org/10.1016/j.molstruc.2010.12.004

Qiu, H., Lv, L., Pan, B.C., Zhang, Q.J., Zhang, W.M., Zhang, Q.X., 2009. Critical review in adsorption kinetic models. J. Zhejiang Univ. Sci. A 10, 716-724. https://doi.org/10.1631/jzus.A0820524

Qua, E.H., Hornsby, P.R., Sharma, H.S.S., Lyons, G., 2011. Preparation and characterisation of cellulose nanofibres. J. Mater. Sci. 46, 6029-6045. https://doi.org/10.1007/s10853011-5565-X

Ren, C., Ding, X., Li, W., Wu, H., Yang, H., 2017. Highly Efficient Adsorption of Heavy Metals onto Novel Magnetic Porous Composites Modified with Amino Groups. J. Chem. Eng. Data 62, 1865-1875. https://doi.org/10.1021/acs.jced.7b00198

Ren, Z., Zhang, G., Paul Chen, J., 2011. Adsorptive removal of arsenic from water by an ironzirconium binary oxide adsorbent. J. Colloid Interface Sci. 358, 230-237. https://doi.org/10.1016/j.jcis.2011.01.013

Serin, B., Ellickson, R.T., 1941. Determination of Diffusion Coefficients. J. Chem. Phys. 9, 
742. https://doi.org/10.1063/1.1750834

Serrano, L., Esakkimuthu, E.S., Marlin, N., Brochier-Salon, M.C., Mortha, G., Bertaud, F., 2018. Fast, Easy, and Economical Quantification of Lignin Phenolic Hydroxyl Groups: Comparison with Classical Techniques. Energy and Fuels 32, 5969-5977. https://doi.org/10.1021/acs.energyfuels.8b00383

Shen, W., Chen, S., Shi, S., Li, X., Zhang, X., Hu, W., Wang, H., 2009. Adsorption of Cu(II) and $\mathrm{Pb}(\mathrm{II})$ onto diethylenetriamine-bacterial cellulose. Carbohydr. Polym. 75, 110-114. https://doi.org/10.1016/j.carbpol.2008.07.006

Shen, X., Xie, Y., Wang, Q., Yi, X., Shamshina, J.L., Rogers, R.D., 2019. Enhanced heavy metal adsorption ability of lignocellulosic hydrogel adsorbents by the structural support effect of lignin. Cellulose 26, 4005-4019. https://doi.org/10.1007/s10570-019-02328-w

Shukla, S.R., Pai, R.S., 2005. Adsorption of $\mathrm{Cu}(\mathrm{II}), \mathrm{Ni}(\mathrm{II})$ and $\mathrm{Zn}(\mathrm{II})$ on modified jute fibres. Bioresour. Technol. 96, 1430-1438. https://doi.org/10.1016/j.biortech.2004.12.010

Soldatkina, L., Zavrichko, M., 2018. Equilibrium, Kinetic, and Thermodynamic Studies of Anionic Dyes Adsorption on Corn Stalks Modified by Cetylpyridinium Bromide. Colloids and Interfaces 3, 4. https://doi.org/10.3390/colloids3010004

Sugiyama, S., Ichii, T., Hayashi, H., Tomida, T., 2002. Lead immobilization by non-apatitetype calcium phosphates in aqueous solutions. Inorg. Chem. Commun. 5, 156-158. https://doi.org/10.1016/S1387-7003(02)00326-X

Viegas, R.M.C., Campinas, M., Costa, H., Rosa, M.J., 2014. How do the HSDM and Boyd's model compare for estimating intraparticle diffusion coefficients in adsorption processes. Adsorption 20, 737-746. https://doi.org/10.1007/s10450-014-9617-9

Xu, F., Yu, J., Tesso, T., Dowell, F., Wang, D., 2013. Qualitative and quantitative analysis of lignocellulosic biomass using infrared techniques: A mini-review. Appl. Energy 104, 801-809. https://doi.org/10.1016/j.apenergy.2012.12.019

Xu, Q., Wang, Yulu, Jin, L., Wang, Yu, Qin, M., 2017. Adsorption of $\mathrm{Cu}$ (II), $\mathrm{Pb}$ (II) and $\mathrm{Cr}$ (VI) from aqueous solutions using black wattle tannin-immobilized nanocellulose. J. Hazard. Mater. 339, 91-99. https://doi.org/10.1016/j.jhazmat.2017.06.005

Yao, S., Gao, C., Nie, S., Niu, F., Wang, S., Qin, C., 2017. Effects of formaldehyde modification of eucalyptus bark on Cr(VI) adsorption. BioResources 12, 8986-9000. https://doi.org/10.15376/biores.12.4.8986-9000

Yuan, T., Meng, J., Gong, X., Zhang, Y., Xu, M., 2013. Modulating pore size and surface properties of cellulose microporous membrane via thio-ene chemistry. Desalination 328 , 58-66. https://doi.org/10.1016/j.desal.2013.08.020 
Zelmanov, G., Semiat, R., 2011. Iron $(\mathrm{Fe}+3)$ oxide/hydroxide nanoparticles-based agglomerates suspension as adsorbent for chromium $(\mathrm{Cr}+6)$ removal from water and recovery. Sep. Purif. Technol. 80, 330-337. https://doi.org/10.1016/j.seppur.2011.05.016

Zhang, X., Wang, X., 2015. Adsorption and desorption of Nickel(II) ions from aqueous solution by a lignocellulose/montmorillonite nanocomposite. PLoS One 10, 1-21. https://doi.org/10.1371/journal.pone.0117077

Zhou, Y., Jin, Q., Zhu, T., Akama, Y., 2011. Adsorption of chromium (VI) from aqueous solutions by cellulose modified with $\beta$-CD and quaternary ammonium groups. J. Hazard. Mater. 187, 303-310. https://doi.org/10.1016/j.jhazmat.2011.01.025

Zhou, Y., Jin, Q., Zhu, T., Ma, T., Hu, X., 2012. Removal of Chromium (VI) from Aqueous Solution by Cellulose Modified with D-Glucose. Sep. Sci. Technol. 47, 157-165. https://doi.org/10.1080/01496395.2011.603139 